Marquette University

e-Publications@Marquette

Economics Faculty Research and Publications

Business Administration, College of

$1-1-2012$

\title{
Drive 'Til You Qualify: Credit Quality and Household Location
}

Andrew Hanson

Marquette University, andrew.r.hanson@marquette.edu

Kurt Schnier

Georgia State University

Geoffrey K. Turnbull

University of Central Florida

Accepted version. Regional Science and Urban Economics, Vol. 42, No. 1-2 (January 2012): 63-77.

DOI. Published under Creative Commons license Attribution-NonCommercial-NoDerivatives 4.0 International.

Andrew Hanson was affiliated with Georgia State University at the time of publication. 


\title{
Drive ‘Til You Qualify: Credit Quality and Household Location
}

\author{
Andrew Hanson \\ Department of Economics, Georgia State University \\ Atlanta, GA \\ Kurt Schnier \\ Department of Economics, Georgia State University \\ Atlanta, GA \\ Geoffrey K. Turnbull \\ Department of Finance, University of Central Florida \\ Orlando, FL
}

\begin{abstract}
A deeper understanding of the credit-sorting process is essential when considering the extent to which home foreclosures are driven by price contagion or an underlying spatial pattern of mortgage quality. Adapting household location theory, we find that credit constrained households follow "drive-'til-you-qualify" behavior leading to rising credit quality with distance from the CBD while unconstrained households exhibit declining credit quality. Individual level mortgage loan-to-income data for the 100 largest MSAs show credit constrained behavior either throughout the urban area or concentrated in the suburbs. Meta analysis of the credit sorting estimates identify MSA characteristics associated with each pattern.
\end{abstract}

Keywords: Mortgage Quality, Spatial Concentration

Regional Science and Urban Economics, Vol 42, No. 1-2 (January 2012): pg. 63-77. DOI. This article is @ Elsevier and permission has been granted for this version to appear in e-Publications@Marquette. Elsevier does not grant permission for this article to be further copied/distributed or hosted elsewhere without the express permission from Elsevier. 
NOT THE PUBLISHED VERSION; this is the author's final, peer-reviewed manuscript. The published version may be accessed by following the link in the citation at the bottom of the page.

\section{Introduction}

Until the recent housing market collapse, economists have paid little attention to the factors determining the spatial distribution of mortgage quality aside from concerns about discriminatory practices in mortgage finance. A deeper understanding of the credit qualitylocation relationship is essential when considering the extent to which subsequent foreclosures are driven by price contagion or an underlying spatial pattern of mortgage quality or both. A fundamental tenant of neoclassical urban economics is that households tend to spatially sort in urban areas by income, family composition, education, etc. ${ }^{1}$ The recent surge in mortgage defaults precipitated by the housing market collapse brings an overlooked but important question into sharper focus: do households also spatially sort by credit quality? The prevailing casual presumption is that the spatial pattern of nonperforming mortgages reflects household incomes. Credit quality, however, varies even across households with identical income and wealth, reflecting a variety of factors not directly addressed in standard household location theory. This distinction is important, since a tendency for otherwise identical households to spatially sort by credit quality can create neighborhoods with relatively high concentrations of low credit quality households, providing fertile ground for the type of mortgage default concentrations that have given rise to recent policy concerns.

This paper examines the implications of two alternative creditquality spatial sorting models. The first is a straightforward extension of the Alonso-Muth partial equilibrium consumer model in which the household's mortgage cost varies with its credit quality. ${ }^{2}$ The credit quality version of the model used here predicts that households will spatially sort to yield declining credit quality and rising loan-to-income ratios with greater distance from the central business district (CBD). The second model depicts a credit-constrained household whose mortgage size is determined by its creditworthiness. In this model, the household's optimal location satisfies "drive-'til-you-qualify" (DTQ) behavior, with the household living as far away from the CBD as it must to exploit lower housing prices and obtain housing that satisfies its credit constraint. DTQ behavior implies that credit-constrained households sort to yield rising credit quality and declining mortgage

Regional Science and Urban Economics, Vol 42, No. 1-2 (January 2012): pg. 63-77. DOI. This article is (C) Elsevier and permission has been granted for this version to appear in e-Publications@Marquette. Elsevier does not grant permission for this article to be further copied/distributed or hosted elsewhere without the express permission from Elsevier. 
debt-to-income ratios with greater distance from the CBD, opposite the pattern predicted for households that are not credit-constrained.

The Alonso-Muth and DTQ models of urban household location predict different credit sorting patterns, hence different predictions for the spatial distribution of likely mortgage defaults. As a result, the spatial pattern of mortgage quality depends on the mix of creditconstrained and unconstrained households in a given urban area. Whether households exhibit unconstrained or DTQ behavior or where they exhibit such behavior in a given city therefore remains an empirical question.

We use HMDA mortgage application and origination data for 2004 to examine the spatial patterns of loan-to-income and credit quality (measured by mortgage denials) for the 100 largest Metropolitan Statistical Areas (MSAs). Using 2004 data allows us to examine the period immediately preceding the recent housing market collapse. We find that many of the MSAs exhibit non-monotonic relationships between household distance from CBD and debt-toincome and credit quality. The patterns reveal that different areas within individual MSAs appear to be dominated by credit constrained and unconstrained households exhibiting drive-'til-you-qualify behavior and credit-pricing behavior, respectively. There are important systematic differences across cities for mortgage debt-to-income ratios and mortgage denial rates. Detroit, Atlanta, Cleveland, San Diego, and Las Vegas, for example, exhibit patterns consistent with interior regions dominated by households subject to credit quality pricing and regions farther toward the periphery dominated by credit constrained households adhering to DTQ behavior. Chicago, Boston, Miami, and Seattle, on the other hand, are examples of MSAs that exhibit the opposite sorting pattern.

The theory implies that the observed spatial pattern of mortgage quality depends on the mix of credit-constrained and unconstrained households in a given urban area. At the same time, the mix of household types depends upon the underlying economic factors driving the long run growth or decline of metropolitan areas. Therefore, we also conduct a meta-analysis of the credit quality sorting patterns to identify MSA-level economic factors associated with the different observed credit quality sorting patterns across MSAs. We find

Regional Science and Urban Economics, Vol 42, No. 1-2 (January 2012): pg. 63-77. DOI. This article is (C) Elsevier and permission has been granted for this version to appear in e-Publications@Marquette. Elsevier does not grant permission for this article to be further copied/distributed or hosted elsewhere without the express permission from Elsevier. 
that factors associated with urban sprawl (local government fragmentation, central city primacy, and household income) make it more likely that the MSA exhibits mortgage quality sorting patterns consistent with unconstrained households in the urban area interior and less likely to exhibit evidence of credit-constrained DTQ households in the suburbs. Declining urban areas are more likely to exhibit mortgage quality sorting consistent with credit-constrained households dominating suburban locations.

The recent empirical literature reinforces concerns about the feedback effects of concentrated mortgage defaults in specific neighborhoods. Immergluck and Smith, 2006, Leventis, 2009 and Lin et al., 2009 offer evidence that foreclosures not only depress the market prices of surrounding houses, but also that the strength of such price effects is sensitive to the spatial concentration of foreclosures. Harding et al. (2009) also find a spatial price effect, but conclude that it is the observable decline in the condition of foreclosed property that is the source of the externality that lowers neighborhood prices and that the effect is extremely localized. The analysis undertaken here does not deal directly with foreclosures; nonetheless, spatial sorting by credit quality is relevant to that concern, given the presumed correlation between credit quality and default risk under normal conditions.

The theory and empirical evidence presented in this paper imply that foreclosure clustering across neighborhoods occurs not only because of the pecuniary externality that has garnered much attention in the recent literature and popular press, but also because of endogenous spatial household sorting by credit quality. The spatial clustering of defaults and foreclosures may be driven by price contagion effects, but the inability of similarly credit-constrained households to weather the housing market collapse or the recession that followed is likely reinforcing these effects, leading to greater spatial concentration of defaults than would otherwise be observed. Meyer and Pence (2009) offer ancillary empirical evidence regarding consequences of household credit quality sorting; they find subprime mortgages are more strongly associated with zip code credit quality and ethnicity than with income or unemployment. While recently enacted financial market reforms may affect the mix of household types that are owner-occupiers in the next housing market cycle, there

Regional Science and Urban Economics, Vol 42, No. 1-2 (January 2012): pg. 63-77. DOI. This article is (C) Elsevier and permission has been granted for this version to appear in e-Publications@Marquette. Elsevier does not grant permission for this article to be further copied/distributed or hosted elsewhere without the express permission from Elsevier. 
is no reason to expect reforms to modify households' propensity to cluster by credit quality. If spatial sorting by credit quality is a normal feature of housing markets then future housing market declines may raise similar concerns about mortgage default clusters in spite of these reforms.

\section{Credit quality and household location demand}

This section draws upon the Alonso-Muth partial equilibrium consumer demand model to examine the relationship between household credit quality and location demand. We consider the simplest version of the model relevant to the credit quality-location demand question. The urban household has a neoclassical utility function $u(h, y)$ defined over housing, $h$, and spending on all other goods, $y .{ }^{3}$ Consider a household working in the CBD (the results generalize to non-CBD-employed households as well). The commuting cost is $T(k)$, where $k$ is the commuting distance of the residence from the household's (exogenous) job site. The marginal cost of distance is $T_{k}>0$. Given the rental cost of housing at distance $k$ is $R(k)$, the household's problem is to choose its utility maximizing consumption of $h$ and $y$, and location $k$, subject to the location-specific constraint $R(k) h+y+T(k)=I$, where $I$ represents household income. Household location equilibrium satisfies Muth's equation, where the marginal benefit of distance in the form of savings on housing consumption expenditures equals the marginal cost of distance in the form of incremental commuting costs,

$-R_{k} h(R, I-T)=T_{k}$

where $h(R, I-T)$ is the Marshallian or ordinary demand for housing at location $k$.

First consider a household that does not confront a binding credit quantity constraint. The user cost of housing for the household with credit quality $q$ is $c(q)$, where $c^{\prime}<0$ reflects the assumption that mortgage interest rates are lower for households with better credit quality. The market value of housing is $P(k)$, so the rental price is $R(k)=c(q) P(k)$ and Muth's equation becomes

Regional Science and Urban Economics, Vol 42, No. 1-2 (January 2012): pg. 63-77. DOI. This article is (C) Elsevier and permission has been granted for this version to appear in e-Publications@Marquette. Elsevier does not grant permission for this article to be further copied/distributed or hosted elsewhere without the express permission from Elsevier. 


$$
-c(q) P_{k} h(c(q) P, I-T)=T_{k} .
$$

Differentiating with respect to $q$ reveals that higher credit quality decreases the user cost of housing, which increases or decreases the marginal benefit of distance (the left hand side of Muth's equation) as housing demand is price elastic or inelastic, respectively:

$$
\frac{d\left(-c P_{k} h\right)}{d q}=-c^{\prime} P_{k}(1+E(h, R)) \frac{>}{<} 0 \text { as }|E(h, R)| \frac{>}{<} 1 .
$$

Therefore, the household's optimal distance increases or decreases with credit quality as housing demand is elastic or inelastic, respectively:

$$
\frac{d k}{d q} \geq 0 \text { as }|E(h, R)| \frac{>}{<} 1
$$

The long-held consensus is that housing demand is price inelastic (deLeeuw, 1971, Goodman and Kawaii, 1986, Hanushek and Quigley, 1980 and Mayo, 1981), which in turn implies that for households not subject to credit quantity constraint, those with poorer credit quality will locate farther away from the CBD than otherwise identical households with better credit quality.

One of the difficulties with this prediction is that it is not possible to obtain direct measures of individual household credit ratings. We can, however, obtain data for mortgage debt-to-income ratios. Assuming that the typical household finances the proportion $V$ of its house purchase, the mortgage debt-to-income ratio can be expressed as $M=v P h / I$. Differentiating with respect to distance yields the observed spatial pattern of mortgage debt-to-income (holding income constant across distance) as

Regional Science and Urban Economics, Vol 42, No. 1-2 (January 2012): pg. 63-77. DOI. This article is (C) Elsevier and permission has been granted for this version to appear in e-Publications@Marquette. Elsevier does not grant permission for this article to be further copied/distributed or hosted elsewhere without the express permission from Elsevier. 


$$
\frac{d M}{d k}=\left(\frac{v}{I}\right)\left(P_{k} h+P_{k} R\left(\frac{\partial h}{\partial R}\right)-P T_{k}\left(\frac{\partial h}{\partial I^{0}}\right)+P^{2} c^{\prime}\left(\frac{\partial h}{\partial R}\right)\left(\frac{d q}{d k}\right)\right)
$$

where $P=I-T$ is income net of commuting cost and $d q / d k<0$ reflects the equilibrium prediction that households with poorer credit quality live farther out. Substituting the Slutsky equation into the second term and Muth's equation into the third term, this result can be simplified to

$$
\frac{d M}{d k}=\left(\frac{v}{I}\right)\left(P_{k} h\left(1+E(h, R)_{d u=0}\right)+P^{2} c^{\prime}\left(\frac{\partial h}{\partial R}\right)\left(\frac{d q}{d k}\right)\right)<0
$$

where the sign follows for inelastic Hicksian or compensated housing demand (which follows from inelastic Marshallian demand and the assumption that housing is a normal good). Therefore, households that are not subject to a credit quantity constraint will tend to sort themselves in a manner that yields declining mortgage debt-to-income ratios with greater distance from the $C B D$, other things equal.

To build another layer of sophistication into the model, consider a household that is subject to a credit quantity constraint. Denote the non-mortgage debt burden to which the household is committed as $D(q)$, where $D^{\prime}<0$ under the assumption that credit quality is inversely related to (nonmortgage) debt burden. The maximum mortgage that this household can borrow is $\mu(I-D)>0$, where $\mu$ is an underwriting constraint. Since the household's mortgage is $v P h$, the credit constraint is

$$
v P h \leq \mu(I-D)
$$

It is straightforward to show that the unconstrained household examined above satisfies $v P h(R, I-T)<\mu(I-D)$ with strict inequality. Ceteris paribus, stronger tastes for housing (holding $k$ constant) increase the left hand side of the credit constraint (7) and, if strong

Regional Science and Urban Economics, Vol 42, No. 1-2 (January 2012): pg. 63-77. DOI. This article is (C) Elsevier and permission has been granted for this version to appear in e-Publications@Marquette. Elsevier does not grant permission for this article to be further copied/distributed or hosted elsewhere without the express permission from Elsevier. 
enough, lead to a credit constrained household for which the mortgage size constraint holds with equality, or $v P h=\mu(I-D)$. Solving for the allowed housing consumption and substituting into Muth's Eq. (1) yields the location equilibrium condition for the credit constrained household as

$$
\left(\frac{-R_{k}}{R}\right)\left(\frac{\mu}{c v}\right)(I-D)=T_{k} .
$$

This is the "drive-'til-you-qualify" (DTQ) condition: the credit constrained household locates as far out as it must to afford the quantity of housing closest to what would be its unconstrained demand, balanced against the incremental commuting costs. Looking at the left hand side of this condition, both $c$ and $D$ decrease with higher credit quality $q$, so that the marginal benefit of distance under DTQ behavior at a given $k$ increases with higher credit quality: For households subject to credit quantity constraint, those with higher credit quality will locate farther away from the CBD than otherwise identical households with poorer credit quality: the credit constrained household location equilibrium implies $d q / d k>0$. This spatial sorting pattern is opposite that of unconstrained households.

The mortgage debt-to-income ratio for the credit constrained household is $M=\frac{v P h}{I}=\frac{\mu(I-D)}{I}$. Differentiating with respect to distance,

$$
\frac{d M}{d k}=-\frac{\mu}{I} D^{\prime}\left(\frac{d q}{d k}\right)>0
$$

using $d q / d k>0$ under DTQ behavior so that households subject to a credit quantity constraint will tend to sort themselves in a manner that yields rising mortgage debt-to-income ratios with greater distance from the $C B D$, other things equal. This implication contrasts with the prediction for households not under the binding credit constraint.

Regional Science and Urban Economics, Vol 42, No. 1-2 (January 2012): pg. 63-77. DOI. This article is (C) Elsevier and permission has been granted for this version to appear in e-Publications@Marquette. Elsevier does not grant permission for this article to be further copied/distributed or hosted elsewhere without the express permission from Elsevier. 


\section{Data and empirical model}

To test the credit quality sorting patterns implied by household location theory, we use two different dependent variables: the mortgage debt-to-income ratio in census tract $i,\left(D e b t / I_{i}\right.$ and the percentage of mortgage applications denied in census tract $i$, Deniali. We use the following model to estimate the relationship between urban spatial structure and these variables of interest:

$$
\begin{aligned}
& \gamma_{i}=\propto+\beta_{1} \text { Miles }_{i}+\beta_{2} \text { Miles }_{i}^{2}+\beta_{3} \text { Median Income }_{i} \\
& +\beta_{4} \text { Vacancy Rate }_{i}+\beta_{5}{\text { Median Home } \text { Value }_{i}} \\
& +\beta_{6} \text { Employment Rate }_{i}+\beta_{7} \text { College Educated }_{i} \\
& +\beta_{8} \text { Non White }_{i}+\beta_{9} \text { New Residents }_{i} \\
& +\beta_{10} \text { Commute Time } \\
& +\sum_{r=1}^{R} \gamma_{r} D_{i, r}+\varepsilon \gamma_{i} \in(\text { Debt / I), Denial. }
\end{aligned}
$$

Miles is the straight-line distance measured in miles between the center of the census tract and the CBD; we explain the construction of this variable below. All other non-debt related control variables in the empirical models are drawn from the 2000 Census and pertain to census tracts. Median Income is median household income (measured in $\$ 10,000)$. Vacancy Rate is the percentage of total housing units unoccupied, whether for rent, for sale, sold but not occupied, seasonal use, migrant worker use, or other reasons. Median Home Value is the self-reported median value of owner-occupied units. Employment Rate is the percentage of the total working age population employed during the census year. College Educated is the percentage of the adult population 25 years or older that has at least a four-year college degree. Non White is the percentage of the total population not reporting white as their primary racial group. New Residents is the percentage of residents not living in their current location five years ago. Commute Time is the average minutes that residents of the census tract usually travel to work one-way using all forms of transportation. The $D_{r, i}$ represent a set of dummy variables for the direction of the census tract relative to the central business district; $r$ represents a

Regional Science and Urban Economics, Vol 42, No. 1-2 (January 2012): pg. 63-77. DOI. This article is (C) Elsevier and permission has been granted for this version to appear in e-Publications@Marquette. Elsevier does not grant permission for this article to be further copied/distributed or hosted elsewhere without the express permission from Elsevier. 
directional control, an indicator for tracts in the NE, NW, SE, or SW quadrant relative to the CBD. ${ }^{4}$ We include these variables in the empirical models to control for a range of household characteristics that may influence household housing and debt decisions. Some may be endogenous with our credit quality measures. In any case, we are not concerned with the overall explanatory power of the control variables or whether their point estimates are consistent. Instead, our focus is on the distance parameter estimates $\beta_{1}$ and $\beta_{2}$; these estimates appear qualitatively robust to including or excluding various household characteristics controls in the empirical models.

Turning to the variables of central interest, to calculate the Miles and Miles $^{2}$ variables we first approximate the metropolitan area CBD of each of the 100 largest metropolitan areas in the country using the location of the tallest building in the primary city. In most cases we obtained information on the tallest building in each primary city from Emporis (www.emporis.com), a commercial real estate data provider. ${ }^{5}$ We geocode the locations for each building and calculate the distance (and direction) between the nearest CBD and all census tracts in the U.S. We estimate Eq. (10) and its variants using only census tracts within 70 miles of a CBD, which leaves a sample of 51,567 tracts (out of 65,132 total tracts).

For metropolitan areas with two primary cities, like Minneapolis - Saint Paul, MN, we find the tallest building in each primary city and allow our distance measure to be the shortest distance between the census tract and either CBD. For these multiple CBD cities we use all tracts within 70 miles of either CBD in the same regression. Multiple CBD cities in our data set include Washington D.C./Baltimore, Minneapolis/Saint Paul, San Francisco/San Jose, and Dallas/Fort Worth.

Both the mortgage loan-to-income ratio, (Debt/I) , and the percentage of mortgages denied, Deniali, for each census tract are drawn from the Home Mortgage Disclosure Act (HMDA) data base collected by the Federal Financial Institutions Examination Council. ${ }^{6}$ The data are for loans and applications during the calendar year 2004, which precedes the onset of the U.S. housing market collapse in 200708 and the attendant turmoil in mortgage and financial markets.

Regional Science and Urban Economics, Vol 42, No. 1-2 (January 2012): pg. 63-77. DOI. This article is (C) Elsevier and permission has been granted for this version to appear in e-Publications@Marquette. Elsevier does not grant permission for this article to be further copied/distributed or hosted elsewhere without the express permission from Elsevier. 
Focusing on the period well before the crash allows us to examine the implications of standard lending practices during the pre-crisis period. As such, the empirical results for the single year studied here may or may not generalize to earlier or later years.

The 2004 HMDA dataset contains approximately 33.6 million loan records from 8853 financial institutions. The data include both mortgage amounts (designated as debt, here) and income reported to the lender as well as samples of denied applications. The HMDA data also indicate the census tract of the property location where the loan is originated or the application received. We use only the data on conventional loans originated for owner-occupied one to four family homes to create a mortgage loan-to-income ratio, (Debt/ $)_{i}$, for each census tract in our sample. We also calculate the mortgage denial rate, Deniali, for conventional loans on owner-occupied one to four family home applications; this variable is the number of mortgage denials divided by the number of applications in each census tract.

Given our hypothesis regarding the spatial sorting of urban households, we are primarily interested in the coefficients on Miles and $\operatorname{Miles}^{2}$ ( $\beta_{1}$ and $\beta_{2}$, respectively). In light of the theory, the signs and magnitudes of these coefficients indicate the spatial pattern of urban household sorting by credit quality, if any. For the empirical debt-toincome model, positive marginal effects $\left(\beta_{1}+2 \beta_{2}\right.$ Miles $\left._{i}>0\right)$ indicate sorting consistent with credit constrained drive-'till-you-qualify (DTQ) behavior while negative marginal effects $\left(\beta_{1}+2 \beta_{2}\right.$ Miles $\left._{i}<0\right)$ indicate sorting consistent with the Alonso-Muth credit pricing model of the unconstrained borrower. For the empirical mortgage denials model, positive marginal effects $\left(\beta_{1}+2 \beta_{2}\right.$ Miles $\left._{i}>0\right)$ indicate sorting consistent with the credit pricing model while negative marginal effects $\left(\beta_{1}+2 \beta_{2}\right.$ Miles $\left._{i}<0\right)$ indicate sorting consistent with credit constrained DTQ behavior.

\section{Empirical results}

\subsection{Mortgage debt-to-income ratio analysis}

The key observable predictions of the household location theory pertain to the mortgage debt-to-income ratio across locations, given

Regional Science and Urban Economics, Vol 42, No. 1-2 (January 2012): pg. 63-77. DOI. This article is (C) Elsevier and permission has been granted for this version to appear in e-Publications@Marquette. Elsevier does not grant permission for this article to be further copied/distributed or hosted elsewhere without the express permission from Elsevier. 
other household characteristics. The first column in Table 1 reports the results of estimating the full empirical model (10) using debt-toincome ratio as the dependent variable for the pooled sample of 100 MSAs. The pooled estimates show that first and second-order effects of Miles (captured by $\beta_{1}$ and $\beta_{2}$ ) are statistically significant individually and jointly at the $1 \%$ level and imply that the average debt-to-income ratio rises by 2.2 percentage points, or slightly less than $1 \%$ at the mean of 2.25, moving an additional 10 miles from the CBD. Using the coefficient on median income (in $\$ 10,000$ ) as the basis for comparison, this effect implies that moving 1 mile farther away from the CBD has the same impact on the observed debt-to-income ratio as $\$ 2743$ less income. Given the concavity of the impact that Miles has on the debtto-income ratio, the marginal effect decreases with additional distance from the CBD. For instance, at a distance of 10 miles moving out an additional mile has the same effect on debt-to-income ratio as an income loss of $\$ 1947$. Although debt-to-income rises as we move away from the $\mathrm{CBD}$, eventually it peaks and begins to decline for areas far enough from the urban core. Panel A of Fig. 1 depicts the estimated quadratic debt-to-income and CBD distance pattern. Taken at face value, the pattern is consistent with unconstrained credit pricing household location theory for areas nearer the CBD and credit constrained DTQ behavior farther out.

Table 1.

Debt-to-income ratio and distance to city center, select old large cities.

\begin{tabular}{|c|c|c|c|}
\hline & $\begin{array}{c}\text { (1) } \\
\text { All cities }\end{array}$ & $\begin{array}{c}(2) \\
\text { New York }\end{array}$ & $\begin{array}{c}\text { (3) } \\
\text { Chicago }\end{array}$ \\
\hline Distance from CBD (in miles) & $\begin{array}{l}0.0032^{* * *} \\
(0.0005)\end{array}$ & $\begin{array}{l}-0.0059^{*} \\
(0.0031)\end{array}$ & $\begin{array}{l}-0.0217^{* * *} \\
(0.0049)\end{array}$ \\
\hline Distance from $\mathrm{CBD}^{2}$ & $\begin{array}{l}-0.0001^{* * *} \\
(0.0000)\end{array}$ & $\begin{array}{l}<0.0001 \\
(0.0001)\end{array}$ & $\begin{array}{l}0.0002^{* * *} \\
(0.0001)\end{array}$ \\
\hline Median income $(\$ 10,000)$ & $\begin{array}{l}-0.0113^{* * *} \\
(0.0000)\end{array}$ & $\begin{array}{l}0.0198^{* * *} \\
(0.0000)\end{array}$ & $\begin{array}{l}0.0393^{* * *} \\
(0.0000)\end{array}$ \\
\hline Vacant units (as \% of total) & $\begin{array}{l}-0.0032^{* * *} \\
(0.0003)\end{array}$ & $\begin{array}{l}-0.0003 \\
(0.0015)\end{array}$ & $\begin{array}{l}0.0022 \\
(0.0022)\end{array}$ \\
\hline Median home value $(\$ 100,000)$ & $\begin{array}{l}0.2260^{* * *} \\
(0.0000)\end{array}$ & $\begin{array}{l}0.0668^{* * *} \\
(0.0000)\end{array}$ & $\begin{array}{l}0.0466^{* * *} \\
(0.0000)\end{array}$ \\
\hline
\end{tabular}

Regional Science and Urban Economics, Vol 42, No. 1-2 (January 2012): pg. 63-77. DOI. This article is (C) Elsevier and permission has been granted for this version to appear in e-Publications@Marquette. Elsevier does not grant permission for this article to be further copied/distributed or hosted elsewhere without the express permission from Elsevier. 
NOT THE PUBLISHED VERSION; this is the author's final, peer-reviewed manuscript. The published version may be accessed by following the link in the citation at the bottom of the page.

\begin{tabular}{|c|c|c|c|}
\hline & $\begin{array}{c}(1) \\
\text { All cities }\end{array}$ & $\begin{array}{c}\text { (2) } \\
\text { New York }\end{array}$ & $\begin{array}{c}\text { (3) } \\
\text { Chicago }\end{array}$ \\
\hline Employment rate & $\begin{array}{l}0.8667^{* * *} \\
(0.0248)\end{array}$ & $\begin{array}{l}1.0516^{* * *} \\
(0.1260)\end{array}$ & $\begin{array}{l}0.6192^{* * *} \\
(0.1758)\end{array}$ \\
\hline College educated (as \% of total) & $\begin{array}{l}-0.3733^{* * *} \\
(0.0240)\end{array}$ & $\begin{array}{l}-1.6258^{* * *} \\
(0.1239)\end{array}$ & $\begin{array}{l}-0.8202^{* * *} \\
(0.1627)\end{array}$ \\
\hline Non-white residents (as \% of total) & $\begin{array}{l}0.1233^{* * *} \\
(0.0085)\end{array}$ & $\begin{array}{l}-0.0857^{* *} \\
(0.0420)\end{array}$ & $\begin{array}{l}-0.0831 \\
(0.0615)\end{array}$ \\
\hline New residents (as \% of total) & $\begin{array}{l}0.0087 \\
(0.0144)\end{array}$ & $\begin{array}{l}0.0894 \\
(0.1142)\end{array}$ & $\begin{array}{l}0.1252 \\
(0.1298)\end{array}$ \\
\hline Average commute time & $\begin{array}{l}0.0139^{* * *} \\
(0.0004)\end{array}$ & $\begin{array}{l}0.0071^{* * *} \\
(0.0017)\end{array}$ & $\begin{array}{l}-0.0067^{* *} \\
(0.0027)\end{array}$ \\
\hline $\mathrm{N}$ & 51567 & 4503 & 2024 \\
\hline Adjusted $\mathrm{R}^{2}$ & 0.2334 & 0.0942 & 0.1235 \\
\hline
\end{tabular}

Notes:

(1) All regressions are estimated with a constant and include a set of dummy variables for direction from CBD (SW direction omitted).

(2) All regressions include only census tracts within 70 miles of the city center.

(3) Debt-to-income ratio from FFIEC HMDA data on individual mortgages in 2004.

(4) Census tract characteristics from 2000 Census.

(5) Miles from CBD calculated as the straight-line distance between the center of census tract and tallest building in the MSA.

(6) Coefficients reported as $<0.0001$ indicate a coefficient between 0 and 0.0001 . Coefficients reported as $>-0.0001$ indicate a coefficient between -0.0001 and 0 .

$* * *$ Indicates statistically significant at $1 \%$ level.

$*$ Indicates statistically significant at $10 \%$ level.

$* *$ Indicates statistically significant at $5 \%$ level.

Regional Science and Urban Economics, Vol 42, No. 1-2 (January 2012): pg. 63-77. DOI. This article is (C) Elsevier and permission has been granted for this version to appear in e-Publications@Marquette. Elsevier does not grant permission for this article to be further copied/distributed or hosted elsewhere without the express permission from Elsevier. 


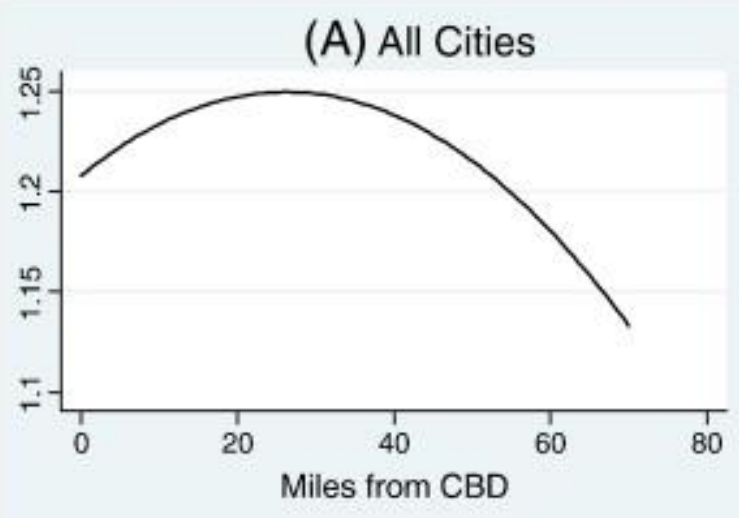

(C) Old, Decaying Cities

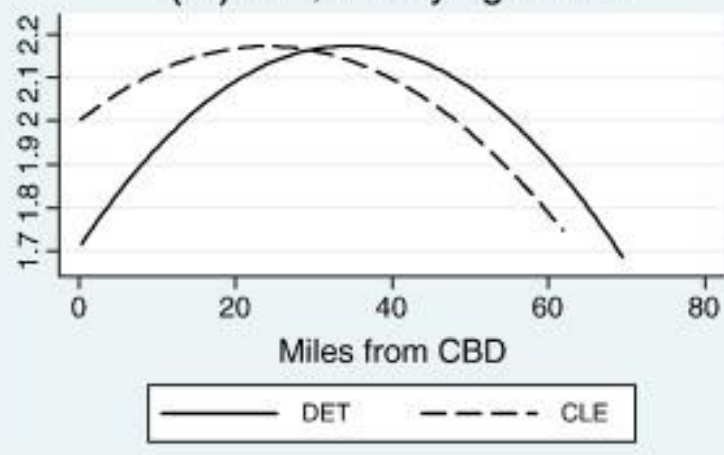

(B) Old, Large Cities

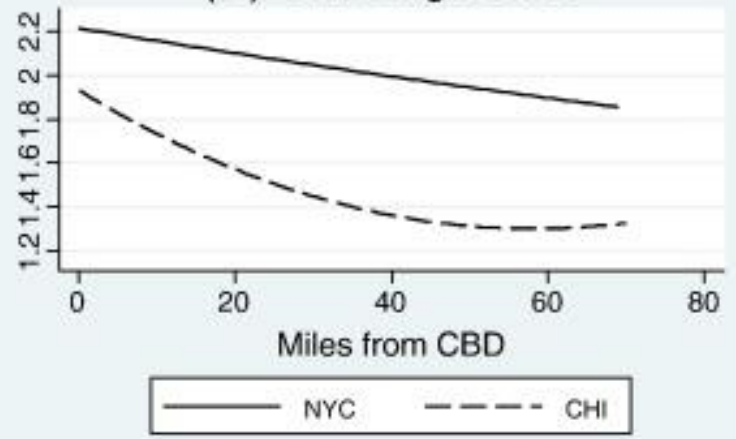

(D) Growing Cities

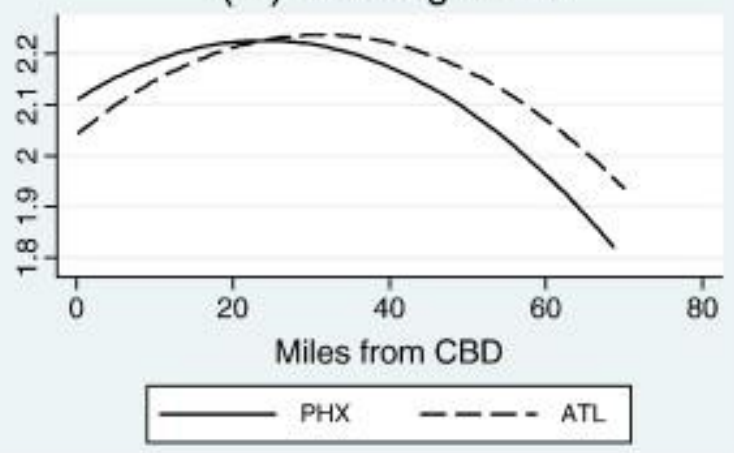

Fig. 1. Quadratic estimates of relationship between debt/income and miles to CBD.

The pooled sample estimates provide a starting point for analysis, but our theoretical explanation suggests the relationship between credit quality and distance may take several forms. It would not be surprising to find differences in the relationship between distance and credit quality across MSAs, given the vast differences in resident composition and city structure found in different MSAs. For example, 1 mile in New York City may not be equivalent to 1 mile in Orlando because of differences in transportation infrastructure, distribution of employment centers, and congestion. Estimating separate models for each urban area controls for these differences to the extent that it allows for the "effective distance" associated with geographic distance to vary across MSAs.

Not surprisingly, the estimates for individual MSAs reveal systematic differences in the debt-to-income pattern over distance. For example, the second and third columns of Table 1 report the estimates for two of the largest MSAs, New York and Chicago. These cities show

Regional Science and Urban Economics, Vol 42, No. 1-2 (January 2012): pg. 63-77. DOI. This article is (C) Elsevier and permission has been granted for this version to appear in e-Publications@Marquette. Elsevier does not grant permission for this article to be further copied/distributed or hosted elsewhere without the express permission from Elsevier. 
the opposite spatial debt-to-income location pattern than the pooled sample. In these cities debt-to-income falls with distance from the $\mathrm{CBD}$ and the magnitude of the decline is large when compared with the pooled estimates. The marginal distance effect of Miles for New York and Chicago imply that moving an additional 10 miles from the CBD lowers the debt-to-income ratio by $5.9 \%$ and $19.7 \%$, respectively. ${ }^{7}$ This represents $2.1 \%$ of the mean (2.78) in New York and $8.1 \%$ of the mean (2.42) in Chicago. Panel B of Fig. 1 portrays the relationship between the debt-to-income ratio and distance to CBD for these cities. Using the point estimates, Fig. 1 illustrates that the nonlinear relationships between Miles and Debt/I exhibit troughs about 295 miles away from the CBD in New York (not statistically significant) and 54 miles in Chicago (statistically significant). Chicago and New York both exhibit the opposite spatial credit quality location pattern found for the pooled sample; in these cities, the patterns are consistent with credit constrained DTQ behavior in the MSA interior with households not subject to credit constraint locating farther out.

Table 2 reports estimates for the archetypical older, declining, rust-belt cities Detroit and Cleveland. The $\beta_{1}$ and $\beta_{2}$ coefficients for both MSAs indicate a concave debt-to-income ratio relative to Milesi, broadly resembling pooled sample (also reported in the table for ease of comparison). The implied marginal effects indicate that moving an additional 10 miles from the CBD raises the debt-to-income ratio by 23.1 and $11.4 \%$ in Detroit and Cleveland, respectively. These increases in the debt-to-income ratio are $10.5 \%$ of the mean (2.19) debt-to-income ratio in Detroit and $5.2 \%$ of the mean (2.19) in Cleveland. These increases are 3 to 5 times those observed in the pooled data. For comparison purposes, Panel C of Fig. 1 displays the estimated debt-to-income ratio and distance relationships for Detroit and Cleveland. The estimated peak debt-to-income ratio occurs at about 34 miles in Detroit and at about 24 miles in Cleveland, both distances well within their respective established MSA boundaries.

Regional Science and Urban Economics, Vol 42, No. 1-2 (January 2012): pg. 63-77. DOI. This article is (C) Elsevier and permission has been granted for this version to appear in e-Publications@ Marquette. Elsevier does not grant permission for this article to be further copied/distributed or hosted elsewhere without the express permission from Elsevier. 
NOT THE PUBLISHED VERSION; this is the author's final, peer-reviewed manuscript. The published version may be accessed by following the link in the citation at the bottom of the page.

Table 2. Debt-to-income ratio and distance to city center, select old decaying cities.

\begin{tabular}{|c|c|c|c|}
\hline & $\begin{array}{c}\text { (1) } \\
\text { All cities }\end{array}$ & $\begin{array}{c}\text { (2) } \\
\text { Detroit }\end{array}$ & $\begin{array}{c}\text { (3) } \\
\text { Cleveland }\end{array}$ \\
\hline Distance from CBD (in miles) & $\begin{array}{l}0.0032^{* * *} \\
(0.0005)\end{array}$ & $\begin{array}{l}0.0271^{* * *} \\
(0.0044)\end{array}$ & $\begin{array}{l}0.0144^{* *} \\
(0.0056)\end{array}$ \\
\hline Distance from $\mathrm{CBD}^{2}$ & $\begin{array}{l}-0.0001^{* * *} \\
(0.0000)\end{array}$ & $\begin{array}{l}-0.0004^{* * *} \\
(0.0001)\end{array}$ & $\begin{array}{l}{ }^{k}-0.0003^{* * *} \\
(0.0001)\end{array}$ \\
\hline Median income & $\begin{array}{l}-0.0113^{* * *} \\
(0.0000)\end{array}$ & $\begin{array}{l}-0.0401^{* * *} \\
(0.0000)\end{array}$ & $\begin{array}{l}0.0138 \\
(0.0000)\end{array}$ \\
\hline Vacant units (as \% of total) & $\begin{array}{l}-0.0032^{* * *} \\
(0.0003)\end{array}$ & $\begin{array}{l}-0.0021 \\
(0.0013)\end{array}$ & $\begin{array}{l}-0.0001 \\
(0.0023)\end{array}$ \\
\hline Median home value & $\begin{array}{l}0.2260^{* * *} \\
(0.0000)\end{array}$ & $\begin{array}{l}0.1700^{* * *} \\
(0.0000)\end{array}$ & $\begin{array}{l}0.1120^{* *} \\
(0.0000)\end{array}$ \\
\hline Employment rate & $\begin{array}{l}0.8667^{* * *} \\
(0.0248)\end{array}$ & $\begin{array}{l}0.7095^{* * *} \\
(0.1472)\end{array}$ & $\begin{array}{l}0.6055^{* * *} \\
(0.2176)\end{array}$ \\
\hline College educated (as $\%$ of total) & $\begin{array}{l}-0.3733^{* * *} \\
(0.0240)\end{array}$ & $\begin{array}{l}-0.1530 \\
(0.1327)\end{array}$ & $\begin{array}{l}-0.7938^{* * *} \\
(0.1957)\end{array}$ \\
\hline Non-white residents (as \% of total) & $\begin{array}{l}0.1233^{* * *} \\
(0.0085)\end{array}$ & $\begin{array}{l}-0.3126^{* * *} \\
(0.0493)\end{array}$ & $\begin{array}{l}0.2122^{* * *} \\
(0.0838)\end{array}$ \\
\hline New residents (as \% of total) & $\begin{array}{l}0.0087 \\
(0.0144)\end{array}$ & $\begin{array}{l}-0.3476^{* * *} \\
(0.1037)\end{array}$ & $\begin{array}{l}{ }^{k}-0.6882^{* * *} \\
(0.1607)\end{array}$ \\
\hline Average commute time & $\begin{array}{l}0.0139^{* * *} \\
(0.0004)\end{array}$ & $\begin{array}{l}0.0025 \\
(0.0029)\end{array}$ & $\begin{array}{l}-0.0015 \\
(0.0047)\end{array}$ \\
\hline $\mathrm{N}$ & 51567 & 1277 & 727 \\
\hline Adjusted $\mathrm{R}^{2}$ & 0.2334 & 0.3487 & 0.095 \\
\hline
\end{tabular}

Notes:

(1) All regressions are estimated with a constant and include a set of dummy variables for direction from CBD (SW direction omitted).

(2) All regressions include only census tracts within 70 miles of the city center.

(3) Debt-to-income ratio from FFIEC HMDA data on individual mortgages in 2004.

(4) Census tract characteristics from 2000 Census.

(5) Miles from CBD calculated as the straight-line distance between the center of the census tract and the tallest building in the MSA.

(6) Median Income in tens of thousands of dollars.

(7) Median Home Value in hundreds of thousands of dollars.

Regional Science and Urban Economics, Vol 42, No. 1-2 (January 2012): pg. 63-77. DOI. This article is (C) Elsevier and permission has been granted for this version to appear in e-Publications@Marquette. Elsevier does not grant permission for this article to be further copied/distributed or hosted elsewhere without the express permission from Elsevier. 
Table 3 reports estimates for select cities representative of newer, fast-growing, sun-belt cities: Atlanta and Phoenix. The first and second order effects for Miles $i$ generate spatial sorting by credit quality similar to that found for Detroit and Cleveland. As in the cases of Detroit and Cleveland, the calculated marginal distance effects are substantially larger than for the pooled sample. For Atlanta, moving 10 miles from the CBD raises the average debt-to-income ratio by 10.5 percentage points, or $4.7 \%$ at the mean of 2.23 . Within Phoenix, moving 10 miles from the CBD raises the debt-to-income ratio by 7.7 percentage points, or 3.5\% at the mean of 2.21 . As in previous cases, the relationship between Milesi $_{i}$ and the debt-to-income ratio is nonlinear. Panel D in Fig. 1 shows the debt-to-income ratio and distance for Atlanta and Phoenix. According to the point estimates, the peak debt-to-income ratio occurs at 31.25 miles from the CBD in Atlanta, and at 24.25 miles from the CBD in Phoenix. Estimating the relationship between distance and debt-to-income for each city separately allows us to see the difference in credit quality sorting patterns across different types of cities.

Table 3. Debt-to-income ratio and distance to city center, select growing cities.

\begin{tabular}{|c|c|c|c|}
\hline & $\begin{array}{c}(1) \\
\text { All cities }\end{array}$ & $\begin{array}{c}\text { (2) } \\
\text { Atlanta }\end{array}$ & $\begin{array}{c}\text { (3) } \\
\text { Phoenix }\end{array}$ \\
\hline Distance from CBD (in miles) & $\begin{array}{l}0.0032^{* * *} \\
(0.0005)\end{array}$ & $\begin{array}{l}0.0125^{* * *} \\
(0.0025)\end{array}$ & $\begin{array}{l}0.0097^{* *} \\
(0.0044)\end{array}$ \\
\hline Distance from $\mathrm{CBD}^{2}$ & $\begin{array}{l}-0.0001^{* * *} \\
(0.0000)\end{array}$ & $\begin{array}{l}-0.0002^{* * *} \\
(0.0000)\end{array}$ & $\begin{array}{l}-0.0002^{* * *} \\
(0.0001)\end{array}$ \\
\hline Median income & $\begin{array}{l}-0.0113^{* * *} \\
(0.0000)\end{array}$ & $\begin{array}{l}-0.0011^{*} \\
(0.0000)\end{array}$ & $\begin{array}{l}0.0062 \\
(0.0000)\end{array}$ \\
\hline Vacant units (as \% of total) & $\begin{array}{l}-0.0032^{* * *} \\
(0.0003)\end{array}$ & $\begin{array}{l}0.0027^{*} \\
(0.0016)\end{array}$ & $\begin{array}{l}0.0003 \\
(0.0017)\end{array}$ \\
\hline Median home value & $\begin{array}{l}0.2260^{* * *} \\
(0.0000)\end{array}$ & $\begin{array}{l}0.0337 \\
(0.0000)\end{array}$ & $\begin{array}{l}0.1640^{* * *} \\
(0.0000)\end{array}$ \\
\hline Employment rate & $\begin{array}{l}0.8667^{* * *} \\
(0.0248)\end{array}$ & $\begin{array}{l}0.6303^{* * *} \\
(0.1023)\end{array}$ & $\begin{array}{l}0.0002 \\
(0.0966)\end{array}$ \\
\hline College educated (as \% of total) & $\begin{array}{l}-0.3733^{* * *} \\
(0.0240)\end{array}$ & $\begin{array}{l}-0.2667^{* * *} \\
(0.1022)\end{array}$ & $\begin{array}{l}-0.5590^{* * *} \\
(0.1842)\end{array}$ \\
\hline Non-white residents (as \% of total) & $\begin{array}{l}0.1233^{* * *} \\
(0.0085)\end{array}$ & $\begin{array}{l}0.1154^{* * *} \\
(0.0444)\end{array}$ & $\begin{array}{l}0.1001^{*} \\
(0.0550)\end{array}$ \\
\hline
\end{tabular}

Regional Science and Urban Economics, Vol 42, No. 1-2 (January 2012): pg. 63-77. DOI. This article is (C) Elsevier and permission has been granted for this version to appear in e-Publications@Marquette. Elsevier does not grant permission for this article to be further copied/distributed or hosted elsewhere without the express permission from Elsevier. 
NOT THE PUBLISHED VERSION; this is the author's final, peer-reviewed manuscript. The published version may be accessed by following the link in the citation at the bottom of the page.

\begin{tabular}{llll} 
& \multicolumn{1}{c}{$(\mathbf{1})$} & \multicolumn{1}{c}{$(\mathbf{2})$} & \multicolumn{1}{c}{$(\mathbf{3})$} \\
& \multicolumn{1}{c}{ All cities } & \multicolumn{1}{c}{ Atlanta } & \multicolumn{1}{c}{ Phoenix } \\
New residents (as \% of total) & 0.0087 & -0.0743 & -0.1077 \\
& $(0.0144)$ & $(0.0513)$ & $(0.0896)$ \\
Average commute time & $0.0139^{* * *}$ & $-0.0060^{* * *}$ & 0.0004 \\
N & $(0.0004)$ & $(0.0018)$ & $(0.0030)$ \\
Adjusted $\mathrm{R}^{2}$ & 51567 & 823 & 692 \\
& 0.2334 & 0.1543 & 0.1165
\end{tabular}

Notes:

(1) All regressions are estimated with a constant and include a set of dummy variables for direction from CBD (SW direction omitted).

(2) All regressions include only census tracts within 70 miles of the city center.

(3) Debt-to-income ratio from FFIEC HMDA data on individual mortgages in 2004.

(4) Census tract characteristics from 2000 Census.

(5) Miles from CBD calculated as the straight-line distance between the center of the census tract and the tallest building in the MSA.

(6) Median Income in tens of thousands of dollars.

(7) Median Home Value in hundreds of thousands of dollars.

$* * *$ Indicates statistically significant at $1 \%$ level.

$* *$ Indicates statistically significant at $5 \%$ level.

$*$ Indicates statistically significant at $10 \%$ level.

Table 4 reports the $\beta_{1}$ and $\beta_{2}$ estimates for all of the individual MSAs in our sample. ${ }^{8}$ Overall, 22 cities exhibit the same statistically significant (for both $\beta_{1}$ and $\beta_{2}$ ) pattern of debt-to-income ratio peaking within the MSA as observed for Atlanta, Phoenix, Detroit, and Cleveland. Cities that exhibit the statistically significant peak pattern of debt-to-income ratio include: Washington, D.C.-Baltimore, San Diego, Denver, Tampa, Pittsburgh, Cincinnati, Sacramento, Milwaukee, Las Vegas, Raleigh, Jacksonville, and Tucson.

Table 4. Coefficient estimates of debt to income ratio and distance to city center, all cities.

\begin{tabular}{|c|c|c|c|c|c|c|c|}
\hline City & $\begin{array}{l}\text { Distance } \\
\text { from CBD }\end{array}$ & $\begin{array}{l}\text { Distance } \\
\text { from } \text { CBD }^{2}\end{array}$ & $\mathbf{N}$ & $\begin{array}{l}\text { Adjusted } \\
\mathbf{R}^{2}\end{array}$ & $\begin{array}{l}\text { Quadratic } \\
\text { peak } \\
\text { (trough) }\end{array}$ & $\begin{array}{l}\text { Non- } \\
\text { parametric } \\
\text { peak } \\
\text { (trough) }\end{array}$ & $\begin{array}{l}\text { Non- } \\
\text { parametric } \\
\text { 2nd } \\
\text { peak(trough) }\end{array}$ \\
\hline New York, NY & $-0.0059^{*}$ & $<0.0001$ & 4503 & 0.0942 & (295) & 7.11 & \\
\hline $\begin{array}{l}\text { Los Angeles, } \\
\text { CA }\end{array}$ & 0.0004 & $>-0.0001$ & 3122 & 0.0941 & 5.19 & 22.86 & \\
\hline Chicago, IL & $-0.0217^{* * *}$ & $0.0002^{* * *}$ & 2024 & 0.1235 & $(54.25)$ & (Edge) & \\
\hline
\end{tabular}

Regional Science and Urban Economics, Vol 42, No. 1-2 (January 2012): pg. 63-77. DOI. This article is @ Elsevier and permission has been granted for this version to appear in e-Publications@Marquette. Elsevier does not grant permission for this article to be further copied/distributed or hosted elsewhere without the express permission from Elsevier. 
NOT THE PUBLISHED VERSION; this is the author's final, peer-reviewed manuscript. The published version may be accessed by following the link in the citation at the bottom of the page.

\begin{tabular}{|c|c|c|c|c|c|c|c|}
\hline City & $\begin{array}{l}\text { Distance } \\
\text { from CBD }\end{array}$ & $\begin{array}{l}\text { Distance } \\
\text { from CBD }{ }^{2}\end{array}$ & $\mathbf{N}$ & $\begin{array}{l}\text { Adjusted } \\
\mathbf{R}^{\mathbf{2}}\end{array}$ & $\begin{array}{l}\text { Quadratic } \\
\text { peak } \\
\text { (trough) }\end{array}$ & $\begin{array}{l}\text { Non- } \\
\text { parametric } \\
\text { peak } \\
\text { (trough) }\end{array}$ & $\begin{array}{l}\text { Non- } \\
\text { parametric } \\
\text { 2nd } \\
\text { peak(trough) }\end{array}$ \\
\hline $\begin{array}{l}\text { Washington- } \\
\text { Baltimore, } \\
\text { DC-MD" }\end{array}$ & $0.0075^{* * *}$ & $-0.0001^{* * *}$ & 1730 & 0.327 & 37.50 & 32.14 & \\
\hline $\begin{array}{l}\text { San } \\
\text { Francisco- } \\
\text { San Jose, CA }{ }^{\#}\end{array}$ & -0.0001 & $>-0.0001$ & 1496 & 0.2056 & NA & 6.73 & \\
\hline $\begin{array}{l}\text { Philadelphia, } \\
\text { PA }\end{array}$ & $0.0099^{* * *}$ & $>-0.0001$ & 1573 & 0.2625 & 156.65 & Edge & \\
\hline Boston, MA & $-0.0118^{* * *}$ & $0.0001^{* *}$ & 1071 & 0.0772 & $(59.00)$ & 4.47 & $(47.29)$ \\
\hline Detroit, MI & $0.0271^{* * *}$ & $-0.0004^{* * *}$ & 1277 & 0.3487 & 33.88 & 39.26 & \\
\hline $\begin{array}{l}\text { Dallas-Fort } \\
\text { Worth, TX }\end{array}$ & $-0.0038^{* * *}$ & $<0.0001^{* * *}$ & 1423 & 0.1181 & $(31.67)$ & 6.79 & \\
\hline Houston, TX & 0.0005 & $>-0.0001$ & 932 & 0.1202 & 6.14 & 9.57 & \\
\hline Atlanta, GA & $0.0125^{* * *}$ & $-0.0002^{* * *}$ & 823 & 0.1543 & 31.25 & 26.14 & \\
\hline Miami, FL & $-0.0075^{* *}$ & $0.0002^{* *}$ & 585 & 0.2175 & $(18.75)$ & Edge & \\
\hline Seattle, WA & $-0.0109^{* * *}$ & $0.0001^{* * *}$ & 845 & 0.2881 & $(54.5)$ & $(33.06)$ & \\
\hline Phoenix, AZ & $0.0097^{* *}$ & $-0.0002^{* * *}$ & 692 & 0.1165 & 24.25 & 6.32 & \\
\hline $\begin{array}{l}\text { Minneapolis- } \\
\text { St. Paul, MN\# }\end{array}$ & $-0.0039^{* * *}$ & $<0.0001$ & 1151 & 0.4039 & $(1572.58)$ & 12.6 & \\
\hline $\begin{array}{l}\text { Cleveland, } \\
\mathrm{OH}\end{array}$ & $0.0144^{* *}$ & $-0.0003^{* * *}$ & 727 & 0.095 & 24.00 & 36.94 & \\
\hline $\begin{array}{l}\text { San Diego, } \\
\text { CA }\end{array}$ & $0.0127^{* *}$ & $-0.0002^{* * *}$ & 691 & 0.2688 & 31.75 & 28.02 & \\
\hline St. Louis, MO & $-0.0080^{* *}$ & 0.0001 & 619 & 0.3912 & $(68.61)$ & 17.91 & \\
\hline Denver, CO & 0.0054 & -0.0001 & 689 & 0.0466 & 34.60 & 5.24 & $(19.19)$ \\
\hline Tampa, FL & $0.0086^{* *}$ & $-0.0002^{* *}$ & 524 & 0.1416 & 21.50 & 41.99 & \\
\hline $\begin{array}{l}\text { Pittsburgh, } \\
\text { PA }\end{array}$ & $0.0097^{* * *}$ & $-0.0002^{* * *}$ & 913 & 0.1491 & 24.25 & 30.2 & \\
\hline Portland, OR & $-0.0070^{* *}$ & $0.0001^{* *}$ & 552 & 0.1406 & $(35.00)$ & $(42.57)$ & \\
\hline $\begin{array}{l}\text { Cincinnati, } \\
\mathrm{OH}\end{array}$ & 0.0075 & $-0.0002^{* *}$ & 369 & 0.1265 & 18.80 & 17.48 & \\
\hline $\begin{array}{l}\text { Sacramento, } \\
\text { CA }\end{array}$ & $0.0164^{* * *}$ & $-0.0002^{* * *}$ & 474 & 0.2268 & 41.00 & 32.68 & \\
\hline $\begin{array}{l}\text { Kansas City, } \\
\text { MO }\end{array}$ & $0.0085^{* *}$ & $-0.0001^{* *}$ & 621 & 0.1961 & 42.50 & 21.7 & \\
\hline $\begin{array}{l}\text { Milwaukee, } \\
\text { WI }\end{array}$ & $0.0096^{* *}$ & $-0.0002^{* * *}$ & 601 & 0.2802 & 24.00 & 32.52 & \\
\hline Orlando, FL & -0.0010 & $>-0.0001$ & 384 & 0.1302 & NA & 10.16 & \\
\hline $\begin{array}{l}\text { Indianapolis, } \\
\text { IN }\end{array}$ & 0.0019 & $-0.0001^{*}$ & 568 & 0.4028 & 9.51 & 10.04 & \\
\hline $\begin{array}{l}\text { San Antonio, } \\
\text { TX }\end{array}$ & 0.0056 & -0.0001 & 362 & 0.3227 & 23.96 & 29.17 & \\
\hline Norfolk, VA & 0.0019 & -0.0001 & 409 & 0.3126 & 16.10 & 12.09 & \\
\hline
\end{tabular}

Regional Science and Urban Economics, Vol 42, No. 1-2 (January 2012): pg. 63-77. DOI. This article is (C) Elsevier and permission has been granted for this version to appear in e-Publications@Marquette. Elsevier does not grant permission for this article to be further copied/distributed or hosted elsewhere without the express permission from Elsevier. 
NOT THE PUBLISHED VERSION; this is the author's final, peer-reviewed manuscript. The published version may be accessed by following the link in the citation at the bottom of the page.

\begin{tabular}{|c|c|c|c|c|c|c|c|}
\hline City & $\begin{array}{l}\text { Distance } \\
\text { from CBD }\end{array}$ & $\begin{array}{l}\text { Distance } \\
\text { from } \text { CBD }^{2}\end{array}$ & $\mathbf{N}$ & $\begin{array}{l}\text { Adjusted } \\
\mathbf{R}^{2}\end{array}$ & $\begin{array}{l}\text { Quadratic } \\
\text { peak } \\
\text { (trough) }\end{array}$ & $\begin{array}{l}\text { Non- } \\
\text { parametric } \\
\text { peak } \\
\text { (trough) }\end{array}$ & $\begin{array}{l}\text { Non- } \\
\text { parametric } \\
\text { 2nd } \\
\text { peak(trough) }\end{array}$ \\
\hline $\begin{array}{l}\text { Las Vegas, } \\
\text { NV }\end{array}$ & $0.0284^{* * *}$ & $-0.0005^{* * *}$ & 344 & 0.1397 & 28.40 & 11.16 & \\
\hline $\begin{array}{l}\text { Columbus, } \\
\mathrm{OH}\end{array}$ & -0.0040 & $>-0.0001$ & 552 & 0.0777 & NA & (Edge) & \\
\hline Charlotte, NC & 0.0025 & $-0.0001^{* *}$ & 449 & 0.0698 & 12.59 & 19.03 & \\
\hline $\begin{array}{l}\text { New Orleans, } \\
\text { LA }\end{array}$ & $-0.0108^{* *}$ & 0.0001 & 474 & 0.2424 & $(62.86)$ & 5.89 & \\
\hline $\begin{array}{l}\text { Salt Lake } \\
\text { City, UT }\end{array}$ & -0.0011 & $<0.0001$ & 412 & 0.0742 & $(15.14)$ & 13.03 & $(39.18)$ \\
\hline $\begin{array}{l}\text { Greensboro, } \\
\text { NC }\end{array}$ & -0.0003 & $<0.0001$ & 383 & 0.1229 & $(13.31)$ & $(47.97)$ & \\
\hline Austin, TX & 0.0131 & -0.0001 & 356 & 0.1793 & 46.37 & 41.24 & \\
\hline Nashville, TN & 0.0035 & -0.0001 & 360 & 0.1471 & 23.73 & 11.2 & \\
\hline $\begin{array}{l}\text { Providence, } \\
\text { RI }\end{array}$ & $-0.008^{*}$ & 0.0002 & 521 & 0.1274 & $(26.63)$ & 18.38 & $(36.51)$ \\
\hline Raleigh, NC & $0.0061^{*}$ & $-0.0001^{* *}$ & 427 & 0.2602 & 30.50 & (Edge) & \\
\hline Hartford, СТ & $0.0065^{* *}$ & $<0.0001$ & 728 & 0.2661 & NA & 47.31 & \\
\hline Buffalo, NY & $-0.0117^{* * *}$ & $0.0002^{* * *}$ & 390 & 0.3601 & $(29.25)$ & 14.61 & \\
\hline Memphis, TN & 0.0080 & -0.0001 & 400 & 0.1184 & 26.90 & 20.98 & \\
\hline $\begin{array}{l}\text { West Palm } \\
\text { Beach, FL }\end{array}$ & 0.0072 & $-0.0003^{* *}$ & 364 & 0.1945 & 12.02 & 13.26 & \\
\hline $\begin{array}{l}\text { Jacksonville, } \\
\text { FL }\end{array}$ & $0.0128^{* * *}$ & $-0.0002^{* * *}$ & 298 & 0.2088 & 32.00 & 14.73 & \\
\hline Rochester, NY & $-0.0155^{* * *}$ & $0.0002^{* *}$ & 293 & 0.3058 & $(38.75)$ & 11.59 & \\
\hline $\begin{array}{l}\text { Grand } \\
\text { Rapids, MI }\end{array}$ & $-0.0076^{* * *}$ & 0.0001 & 269 & 0.3687 & $(59.10)$ & (Edge) & \\
\hline $\begin{array}{l}\text { Oklahoma } \\
\text { City, OK }\end{array}$ & $-0.0177^{* * *}$ & $0.0002^{* * *}$ & 426 & 0.3639 & $(44.25)$ & 10.82 & \\
\hline Louisville, KY & -0.0088 & 0.0001 & 100 & 0.3246 & $(86.24)$ & $(12.27)$ & \\
\hline Richmond, VA & 0.0027 & $>-0.0001$ & 338 & 0.217 & 57.28 & 40.15 & \\
\hline $\begin{array}{l}\text { Greenville, } \\
\text { SC }\end{array}$ & 0.0038 & -0.0001 & 352 & 0.1374 & 35.91 & 24.01 & \\
\hline Dayton, $\mathrm{OH}$ & $0.0061^{* *}$ & $-0.0001^{*}$ & 408 & 0.1713 & 30.50 & 22.17 & \\
\hline Fresno, CA & $-0.0213^{* * *}$ & $0.0004^{* * *}$ & 258 & 0.179 & $(26.63)$ & 6.69 & $(36.92)$ \\
\hline $\begin{array}{l}\text { Birmingham, } \\
\text { AL }\end{array}$ & 0.0002 & $>-0.0001$ & 461 & 0.2475 & 2.31 & 4.92 & \\
\hline Albany, NY & $0.0092^{* * *}$ & $-0.0001^{*}$ & 433 & 0.4116 & 46.00 & 45.51 & \\
\hline Tucson, AZ & $0.0227^{* * *}$ & $-0.0004^{* * *}$ & 223 & 0.2232 & 28.38 & $(3.68)$ & 16.09 \\
\hline Tulsa, OK & -0.0024 & -0.0001 & 348 & 0.2573 & NA & 9.35 & \\
\hline Syracuse, NY & $-0.0051^{*}$ & $0.0001^{*}$ & 386 & 0.2441 & $(25.50)$ & 25.92 & \\
\hline Omaha, NE & 0.0032 & $>-0.0001$ & 358 & 0.2944 & 34.51 & 11.8 & \\
\hline
\end{tabular}

Regional Science and Urban Economics, Vol 42, No. 1-2 (January 2012): pg. 63-77. DOI. This article is (C) Elsevier and permission has been granted for this version to appear in e-Publications@Marquette. Elsevier does not grant permission for this article to be further copied/distributed or hosted elsewhere without the express permission from Elsevier. 
NOT THE PUBLISHED VERSION; this is the author's final, peer-reviewed manuscript. The published version may be accessed by following the link in the citation at the bottom of the page.

\begin{tabular}{|c|c|c|c|c|c|c|c|}
\hline City & $\begin{array}{l}\text { Distance } \\
\text { from CBD }\end{array}$ & $\begin{array}{l}\text { Distance } \\
\text { from CBD² }\end{array}$ & $\mathbf{N}$ & $\begin{array}{l}\text { Adjusted } \\
\mathbf{R}^{2}\end{array}$ & $\begin{array}{l}\text { Quadratic } \\
\text { peak } \\
\text { (trough) }\end{array}$ & $\begin{array}{l}\text { Non- } \\
\text { parametric } \\
\text { peak } \\
\text { (trough) }\end{array}$ & $\begin{array}{l}\text { Non- } \\
\text { parametric } \\
\text { 2nd } \\
\text { peak(trough) }\end{array}$ \\
\hline $\begin{array}{l}\text { Albuquerque, } \\
\text { NM }\end{array}$ & $-0.0339^{* * *}$ & $0.0006^{* * *}$ & 238 & 0.2651 & $(28.25)$ & 4.25 & $(38.54)$ \\
\hline Knoxville, TN & -0.0009 & 0.0001 & 262 & 0.1468 & $(9.23)$ & 24.06 & $(52.52)$ \\
\hline El Paso, TX & $0.0261^{* *}$ & $-0.0004^{* *}$ & 162 & 0.242 & 32.63 & 23.38 & \\
\hline $\begin{array}{l}\text { Bakersfield, } \\
\text { CA }\end{array}$ & -0.0088 & $0.0002^{* *}$ & 167 & 0.5535 & $(22.12)$ & 7.38 & $(34.57)$ \\
\hline Allentown, PA & -0.0047 & $>-0.0001$ & 335 & 0.4994 & NA & 15.12 & $(37.02)$ \\
\hline $\begin{array}{l}\text { Harrisburg, } \\
\text { PA }\end{array}$ & -0.0004 & 0.0001 & 366 & 0.3388 & 3.69 & Edge & \\
\hline Scranton, PA & -0.0017 & $>-0.0001$ & 319 & 0.289 & NA & $(51.45)$ & \\
\hline Toledo, $\mathrm{OH}$ & -0.0017 & $>-0.0001$ & 375 & 0.4245 & NA & 21.09 & \\
\hline $\begin{array}{l}\text { Baton Rouge, } \\
\text { LA }\end{array}$ & 0.0031 & -0.0001 & 302 & 0.2359 & 21.31 & 5.53 & \\
\hline $\begin{array}{l}\text { Youngstown, } \\
\mathrm{OH}\end{array}$ & 0.0028 & -0.0001 & 318 & 0.4599 & 20.71 & 35.02 & \\
\hline $\begin{array}{l}\text { Springfield, } \\
\text { MA }\end{array}$ & 0.0009 & $>-0.0001$ & 239 & 0.1929 & 63.28 & 38.57 & \\
\hline Sarasota, FL & $0.0437^{* * *}$ & -0.0011 & 149 & 0.141 & 19.45 & 23.13 & \\
\hline $\begin{array}{l}\text { Little Rock, } \\
\text { AR }\end{array}$ & -0.0012 & $>-0.0001$ & 267 & 0.3367 & NA & 11.56 & \\
\hline McAllen, TX & 0.0047 & -0.0001 & 188 & 0.0102 & 46.47 & 51.23 & \\
\hline Stockton, CA & $0.0135^{* *}$ & $-0.0003^{*}$ & 151 & 0.3699 & 22.50 & 18.64 & \\
\hline $\begin{array}{l}\text { Charleston, } \\
\text { SC }\end{array}$ & -0.0025 & -0.0001 & 177 & 0.066 & NA & $(23.84)$ & \\
\hline Wichita, KS & -0.0036 & $>-0.0001$ & 210 & 0.4151 & NA & (Edge) & \\
\hline Mobile, AL & -0.0060 & 0.0001 & 217 & 0.2105 & $(42.97)$ & 20.98 & \\
\hline Columbia, SC & -0.0015 & $<0.0001$ & 224 & 0.034 & (37.05) & 12.46 & $(44.89)$ \\
\hline $\begin{array}{l}\text { Colorado } \\
\text { Springs, CO }\end{array}$ & -0.0070 & $>-0.0001$ & 188 & 0.145 & NA & 8.67 & $(38.15)$ \\
\hline $\begin{array}{l}\text { Fort Wayne, } \\
\text { IN }\end{array}$ & 0.0005 & $<0.0001$ & 274 & 0.1246 & NA & 23.84 & \\
\hline $\begin{array}{l}\text { Daytona } \\
\text { Beach, FL }\end{array}$ & -0.0001 & $>-0.0001$ & 88 & 0.3523 & NA & 18.78 & \\
\hline Lakeland, FL & -0.0060 & $<0.0001$ & 171 & 0.2768 & $(81.32)$ & 9.05 & \\
\hline $\begin{array}{l}\text { Johnson City, } \\
\text { TN }\end{array}$ & $0.0240^{* * *}$ & $-0.0003^{* * *}$ & 259 & 0.4077 & 40.00 & 32.06 & \\
\hline \multicolumn{8}{|c|}{ Lexington, KY No data } \\
\hline Augusta, GA & $<0.0001$ & -0.0001 & 162 & 0.1535 & 0.06 & 12.81 & \\
\hline Melbourne, FL & -0.0072 & 0.0001 & 131 & 0.2016 & $(51.09)$ & 6.21 & $(44.64)$ \\
\hline Lancaster, PA & 0.0003 & -0.0001 & 274 & 0.5568 & 1.49 & 15.11 & \\
\hline $\begin{array}{l}\text { Chattanooga, } \\
\text { TN }\end{array}$ & 0.0025 & -0.0001 & 279 & 0.3584 & 21.66 & 24.63 & \\
\hline
\end{tabular}

Regional Science and Urban Economics, Vol 42, No. 1-2 (January 2012): pg. 63-77. DOI. This article is (C) Elsevier and permission has been granted for this version to appear in e-Publications@Marquette. Elsevier does not grant permission for this article to be further copied/distributed or hosted elsewhere without the express permission from Elsevier. 
NOT THE PUBLISHED VERSION; this is the author's final, peer-reviewed manuscript. The published version may be accessed by following the link in the citation at the bottom of the page.

\begin{tabular}{|c|c|c|c|c|c|c|c|}
\hline City & $\begin{array}{l}\text { Distance } \\
\text { from CBD }\end{array}$ & $\begin{array}{l}\text { Distance } \\
\text { from CBD }\end{array}$ & $\mathbf{N}$ & $\begin{array}{l}\text { Adjusted } \\
\mathbf{R}^{2}\end{array}$ & $\begin{array}{l}\text { Quadratic } \\
\text { peak } \\
\text { (trough) }\end{array}$ & $\begin{array}{l}\text { Non- } \\
\text { parametric } \\
\text { peak } \\
\text { (trough) }\end{array}$ & $\begin{array}{l}\text { Non- } \\
\text { parametric } \\
\text { 2nd } \\
\text { peak(trough) }\end{array}$ \\
\hline $\begin{array}{l}\text { Des Moines, } \\
\text { IA }\end{array}$ & -0.0058 & $<0.0001$ & 230 & 0.5927 & (75.25) & 3.72 & \\
\hline $\begin{array}{l}\text { Kalamazoo, } \\
\text { MI }\end{array}$ & -0.0013 & $<0.0001$ & 306 & 0.0306 & (62.02) & 26.5 & \\
\hline Lansing, MI & 0.0031 & -0.0001 & 241 & 0.564 & 13.43 & 45.14 & \\
\hline Modesto, CA & -0.0019 & $>-0.0001$ & 158 & 0.2789 & NA & 10.72 & $(37.61)$ \\
\hline $\begin{array}{l}\text { Fort Myers, } \\
\text { FL }\end{array}$ & $0.0120^{*}$ & $>-0.0001$ & 203 & 0.1532 & 397.35 & Edge & \\
\hline Jackson, MS & $0.0231^{* *}$ & $-0.0004^{* * *}$ & 211 & 0.3174 & 28.88 & 14.28 & \\
\hline Boise City, ID & 0.0058 & -0.0001 & 95 & 0.2763 & 24.69 & (19.64) & 34.09 \\
\hline Madison, WI & $-0.0198^{* * *}$ & 0.0002 & 349 & 0.3601 & $(52.19)$ & 7.23 & $(54.89)$ \\
\hline Spokane, WA & $-0.0107^{*}$ & 0.0001 & 171 & 0.3435 & $(48.42)$ & 37.59 & \\
\hline Pensacola, FL & -0.0009 & $<0.0001$ & 134 & -0.0012 & (19.59) & 17.77 & \\
\hline Canton, $\mathrm{OH}$ & -0.0009 & $>-0.0001$ & 339 & 0.1727 & NA & $(13.89)$ & 19.84 \\
\hline Saginaw, MI & 0.0027 & -0.0001 & 332 & 0.3641 & 21.65 & 17.16 & (23.59) \\
\hline
\end{tabular}

(1) All regressions are estimated with a constant term and control for median income, percentage of vacant units, median home value, employment rate, percentage of college educated adults, percentage of non-white residents, percentage of new residents, average commute time, and a set of dummy variables for direction from the CBD (SW direction omitted).

(2) All regressions include only census tracts within 70 miles of the city center calculated by the straight-line distance between the center of the census tract and the tallest building in the MSA.

(3) Debt to income ratio from FFIEC HMDA data on individual mortgages in 2004.

(4) Peak (Trough) estimates are calculated as the maximum of the equation Debt/Income $=b_{1}$ (miles) $+b_{2}\left(\right.$ miles $\left.^{2}\right)$, or miles $=-b_{1} / 2 b_{2}$.

(5) Coefficients reported as $<0.0001$ indicate a coefficient between 0 and

0.0001 . Coefficients reported as $>-0.0001$ indicate a coefficient between

-0.0001 and 0 .

*Indicates statistically significant at $10 \%$ level.

$* * *$ Indicates statistically significant at $1 \%$ level.

\#Indicates regression estimated with poly-centric model.

**Indicates statistically significant at $5 \%$ level.

Still, the distance at which the debt-to-income ratio peaks differs substantially across cities. Cincinnati has its peak at about 19 miles, which is closest to the CBD for all cities with significant peaks. Almost all of the estimated peak debt-to-income ratios occur between 19 and 35 miles from the CBD, which fall within our distance band of 70 miles used throughout the empirical analysis of individual cities. The only exceptions are Washington D.C.-Baltimore, where the

Regional Science and Urban Economics, Vol 42, No. 1-2 (January 2012): pg. 63-77. DOI. This article is (C) Elsevier and permission has been granted for this version to appear in e-Publications@Marquette. Elsevier does not grant permission for this article to be further copied/distributed or hosted elsewhere without the express permission from Elsevier. 
peak occurs at about 38 miles, and Sacramento, at 41 miles from the CBD.

Not all cities exhibit the concave debt-to-income ratio pattern. Like Chicago, several cities yield declining debt-to-income ratios that eventually come to a trough within sample and then rise with distance from the CBD. There are 11 cities in our sample that exhibit a similar convex pattern with troughs in-sample (less than 70 miles), including Boston, Dallas-Fort Worth, Miami, Seattle, and Portland, OR. For the entire group of these cities, the estimated trough in the debt-toincome ratio occurs between 19 and 59 miles from the CBD. Miami's trough is nearest the CBD in this group, at approximately 19 miles; Boston's trough is furthest from the CBD at 59 miles. The troughs appear to either cluster around 55 miles (e.g., Chicago, Boston, and Seattle) or around 30 miles (e.g., Dallas-Fort Worth, Portland, and Albuquerque).

\subsection{Percentage of denials analysis}

The household location theory also offers predictions regarding the spatial sorting of households by their credit quality. Ex ante credit quality, unfortunately, is a household characteristic that is not directly observable in the data. The HMDA data does, however, report mortgage application denials, which yields our measure of the denial rate, Denial, for each census tract. We interpret higher denial rates as an indicator of a greater proportion of mortgage applications drawn from a tract with a larger proportion of households with poor credit quality. We suspect that this variable provides a downward biased measure of proportion of households with poor credit quality because an unknown proportion of households with poor credit quality do not even apply for mortgages. There may also be an underwriting bias when using denials to proxy for credit quality. For example, Mian and Sufi (2009) conclude that underwriting standards were weaker in lower income census tracts than in higher income census tracts, which implies a heterogeneous relationship between underlying credit quality and observed denial rates across locations within a city.

With these caveats in mind, Table 5 reports the results of estimating the empirical model (10) with the percentage of denied

Regional Science and Urban Economics, Vol 42, No. 1-2 (January 2012): pg. 63-77. DOI. This article is (C) Elsevier and permission has been granted for this version to appear in e-Publications@Marquette. Elsevier does not grant permission for this article to be further copied/distributed or hosted elsewhere without the express permission from Elsevier. 
mortgage applicants, Denial, as the dependent variable for the pooled sample (first column) as well as for New York (second column) and Chicago (third column) estimated separately. The estimated marginal effect of Milesi on Denial in the pooled sample indicate that an additional 10 miles from the CBD reduces the percentage of applicants denied by 0.05 percentage points, or $2.54 \%$ at the mean of 0.0185 . Using the coefficient on Median Income for comparison, the calculated marginal distance effect implies that an additional mile from the CBD has the same impact on the percentage of denied mortgage applications as increasing median income by $\$ 967$. As is the case with the debt-to-income analysis, the distance effect is non-linear so that at 10 miles moving an additional mile from the CBD is equivalent to increasing median income by about $\$ 330$. The mortgage denial rate declines with distance from the $\mathrm{CBD}$, but eventually comes to a trough and begins to increase for areas far enough from the urban core. Panel A of Fig. 2 displays the estimated quadratic relationship between distance and percentage of mortgages denied.

Table 5. Mortgage denial rate and distance to city center, select old large cities.

\begin{tabular}{|c|c|c|c|}
\hline & $\begin{array}{c}\text { (1) } \\
\text { All Cities }\end{array}$ & $\begin{array}{c}(2) \\
\text { New York }\end{array}$ & $\begin{array}{c}\text { (3) } \\
\text { Chicago }\end{array}$ \\
\hline Distance from CBD (in miles) & $\begin{array}{l}-0.0001^{* *} \\
(0.0000)\end{array}$ & $\begin{array}{l}0.0001 \\
(0.0001)\end{array}$ & $\begin{array}{l}-0.0003^{* *} \\
(0.0002)\end{array}$ \\
\hline Distance from $\mathrm{CBD}^{2}$ & $\begin{array}{l}<0.0001^{* * *} \\
(0.0000)\end{array}$ & $\begin{array}{l}>-0.0001 \\
(0.0000)\end{array}$ & $\begin{array}{l}<0.0001^{* *} \\
(0.0000)\end{array}$ \\
\hline Median income & $\begin{array}{l}-0.0007^{* * *} \\
(0.0001)\end{array}$ & $\begin{array}{l}0.0000 \\
(0.0002)\end{array}$ & $\begin{array}{l}-0.0002 \\
(0.0005)\end{array}$ \\
\hline Vacant units (as \% of total) & $\begin{array}{l}>-0.0001 \\
0.0000\end{array}$ & $\begin{array}{l}>-0.0001 \\
(0.0000)\end{array}$ & $\begin{array}{l}-0.0001 \\
(0.0001)\end{array}$ \\
\hline Median home value & $\begin{array}{l}0.0016^{* * *} \\
(0.0002)\end{array}$ & $\begin{array}{l}0.0007^{* * *} \\
(0.0003)\end{array}$ & $\begin{array}{l}-0.0003 \\
(0.0009)\end{array}$ \\
\hline Employment rate & $\begin{array}{l}-0.0109^{* * *} \\
(0.0014)\end{array}$ & $\begin{array}{l}-0.0006 \\
(0.0037)\end{array}$ & $\begin{array}{l}0.0073 \\
(0.0071)\end{array}$ \\
\hline College educated (as \% of total) & $\begin{array}{l}-0.0011 \\
(0.0013)\end{array}$ & $\begin{array}{l}-0.0038 \\
(0.0036)\end{array}$ & $\begin{array}{l}0.0006 \\
(0.0066)\end{array}$ \\
\hline Non-white residents (as \% of total) & $\begin{array}{l}0.0039^{* * *} \\
(0.0005)\end{array}$ & $\begin{array}{l}0.0021^{*} \\
(0.0012)\end{array}$ & $\begin{array}{l}0.0048^{*} \\
(0.0025)\end{array}$ \\
\hline New residents (as \% of total) & $\begin{array}{l}-0.0067^{* * *} \\
(0.0008)\end{array}$ & $\begin{array}{l}-0.0002 \\
(0.0033)\end{array}$ & $\begin{array}{l}-0.0080 \\
(0.0053)\end{array}$ \\
\hline Average commute time & $-0.0001^{* * *}$ & $<0.0001$ & $<0.0001$ \\
\hline
\end{tabular}

Regional Science and Urban Economics, Vol 42, No. 1-2 (January 2012): pg. 63-77. DOI. This article is (C) Elsevier and permission has been granted for this version to appear in e-Publications@Marquette. Elsevier does not grant permission for this article to be further copied/distributed or hosted elsewhere without the express permission from Elsevier. 
NOT THE PUBLISHED VERSION; this is the author's final, peer-reviewed manuscript. The published version may be accessed by following the link in the citation at the bottom of the page.

\begin{tabular}{llll} 
& \multicolumn{1}{c}{$(\mathbf{1})$} & \multicolumn{1}{c}{$(\mathbf{2})$} & \multicolumn{1}{c}{$(\mathbf{3})$} \\
& All Cities & New York & Chicago \\
& $(0.0000)$ & $(0.0000)$ & $(0.0001)$ \\
$\mathrm{N}$ & 51567 & 4503 & 2024 \\
Adjusted $\mathrm{R}^{2}$ & 0.0153 & 0.006 & 0.017
\end{tabular}

\section{Notes:}

(1) All regressions are estimated with a constant and include a set of dummy variables for direction from CBD (SW direction omitted).

(2) All regressions include only census tracts within 70 miles of the city center.

(3) Denial Rate from FFIEC HMDA data on individual mortgages in 2004.

(4) Census tract characteristics from 2000 Census.

(5) Miles from CBD calculated as the straight-line distance between the center of the census tract and the tallest building in the MSA.

(6) Median Income in tens of thousands of dollars.

(7) Median Home Value in hundreds of thousands of dollars.

(8) Coefficients reported as $<0.0001$ indicate a coefficient between 0 and 0.0001 . Coefficients reported as $>-0.0001$ indicate a coefficient between -0.0001 and 0 .

**Indicates statistically significant at $5 \%$ level.

$* * *$ Indicates statistically significant at $1 \%$ level.

*Indicates statistically significant at $10 \%$ level.

Regional Science and Urban Economics, Vol 42, No. 1-2 (January 2012): pg. 63-77. DOI. This article is (C Elsevier and permission has been granted for this version to appear in e-Publications@Marquette. Elsevier does not grant permission for this article to be further copied/distributed or hosted elsewhere without the express permission from Elsevier. 


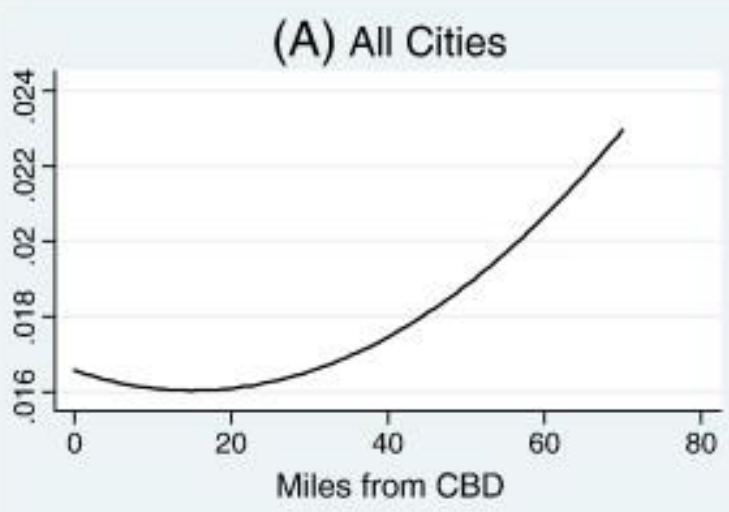

(C) Old, Decaying Cities

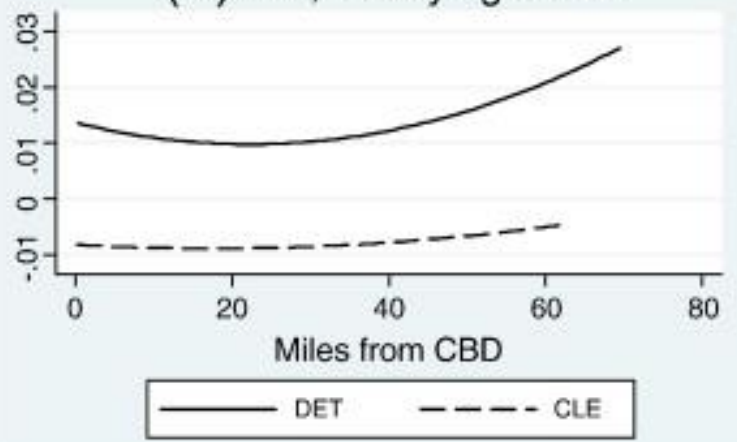

(B) Old, Large Cities

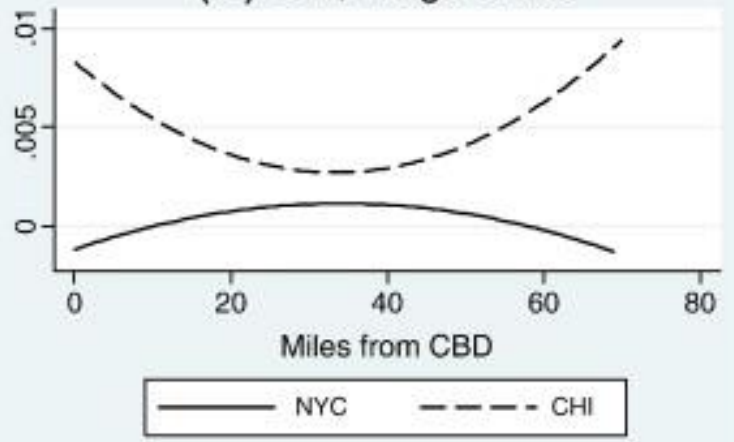

(D) Growing Cities

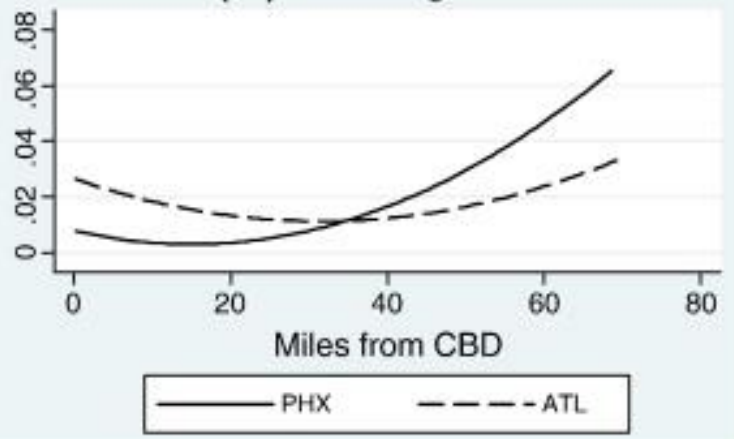

Fig. 2. Quadratic estimates of relationship between denial rate and miles to CBD.

The denial results for Chicago qualitatively resemble the pooled estimates. The magnitude of the $\beta_{1}$ estimate in Chicago is, however, about three times larger than the estimate for the full sample of cities and is significant at the $5 \%$ level. The Chicago estimates imply that moving an additional 10 miles from the CBD lowers the percentage of denied mortgages by 0.29 percentage points, or almost $6 \%$ at the mean of 0.005 . The marginal effect of distance for New York is the opposite sign but not significant at conventional levels. Panel B of Fig. 2 displays the relationship between the percentage of mortgage denials and distance to the CBD for the full sample, New York, and Chicago. The estimates indicate a trough at 33.40 miles from the CBD in Chicago.

Table 6 displays the results of estimating the empirical model using the percentage of denied mortgage applications in a census tract as the dependent variable for our representative older, decaying cities, 


\section{Detroit and Cleveland. The $\beta_{1}$ coefficients for both Detroit and} Cleveland have the same negative sign as the full sample of cities, indicating that the percentage of mortgage applications that are denied declines with distance from the city center. The magnitude of $\beta_{1}$ for Detroit is the same size as the estimate for Chicago, substantially larger than the estimate for the full sample; the estimate for Cleveland is approximately the same as the full sample estimate. Neither Detroit nor Cleveland, however, exhibits statistically significant distance effects.

Table 6. Mortgage denial rate and distance to city center, select old decaying cities.

\begin{tabular}{|c|c|c|c|}
\hline & $\begin{array}{c}(1) \\
\text { All cities }\end{array}$ & $\begin{array}{c}(2) \\
\text { Detroit }\end{array}$ & $\begin{array}{c}\text { (3) } \\
\text { Cleveland }\end{array}$ \\
\hline Distance from CBD (in miles) & $\begin{array}{l}-0.0001^{* *} \\
(0.0000)\end{array}$ & $\begin{array}{l}-0.0003 \\
(0.0005)\end{array}$ & $\begin{array}{l}-0.0001 \\
(0.0002)\end{array}$ \\
\hline Distance from $\mathrm{CBD}^{2}$ & $\begin{array}{l}<0.0001^{* * *} \\
(0.0000)\end{array}$ & $\begin{array}{l}<0.0001 \\
(0.0000)\end{array}$ & $\begin{array}{l}<0.0001 \\
(0.0000)\end{array}$ \\
\hline Median income & $\begin{array}{l}-0.0007^{* * *} \\
(0.0001)\end{array}$ & $\begin{array}{l}0.0019 \\
(0.0013)\end{array}$ & $\begin{array}{l}0.0010 \\
(0.0007)\end{array}$ \\
\hline Vacant units (as\% of total) & $\begin{array}{l}>-0.0001 \\
0.0000\end{array}$ & $\begin{array}{l}-0.0001 \\
(0.0001)\end{array}$ & $\begin{array}{l}0.0001 \\
(0.0001)\end{array}$ \\
\hline Median home value & $\begin{array}{l}0.0016^{* * *} \\
(0.0002)\end{array}$ & $\begin{array}{l}-0.0010 \\
(0.0029)\end{array}$ & $\begin{array}{l}-0.0025 \\
(0.0016)\end{array}$ \\
\hline Employment rate & $\begin{array}{l}-0.0109^{* * *} \\
(0.0014)\end{array}$ & $\begin{array}{l}-0.0118 \\
(0.0152)\end{array}$ & $\begin{array}{l}-0.0095 \\
(0.0067)\end{array}$ \\
\hline College educated (as $\%$ of total) & $\begin{array}{l}-0.0011 \\
(0.0013)\end{array}$ & $\begin{array}{l}-0.0154 \\
(0.0137)\end{array}$ & $\begin{array}{l}-0.0081 \\
(0.0060)\end{array}$ \\
\hline Non-white residents (as\% of total) & $\begin{array}{l}0.0039^{* * *} \\
(0.0005)\end{array}$ & $\begin{array}{l}0.0120^{* *} \\
(0.0051)\end{array}$ & $\begin{array}{l}-0.0039 \\
(0.0026)\end{array}$ \\
\hline New residents (as $\%$ of total) & $\begin{array}{l}-0.0067^{* * *} \\
(0.0008)\end{array}$ & $\begin{array}{l}-0.0055 \\
(0.0107)\end{array}$ & $\begin{array}{l}0.0124^{* *} \\
(0.0049)\end{array}$ \\
\hline Average commute time & $\begin{array}{l}-0.0001^{* * *} \\
(0.0000)\end{array}$ & $\begin{array}{l}>-0.0001 \\
(0.0003)\end{array}$ & $\begin{array}{l}0.0004^{* * *} \\
(0.0001)\end{array}$ \\
\hline $\mathrm{N}$ & 51567 & 1277 & 727 \\
\hline Adjusted $\mathrm{R}^{2}$ & 0.0153 & 0.017 & 0.029 \\
\hline
\end{tabular}

$* * *$ indicates statistically significant at $1 \%$ level, $* *$ at $5 \%$ level, $*$ at $10 \%$ level.

Notes:

(1) All regressions are estimated with a constant and include a set of dummy variables for direction from CBD (SW direction omitted).

(2) All regressions include only census tracts within 70 miles of the city center.

Regional Science and Urban Economics, Vol 42, No. 1-2 (January 2012): pg. 63-77. DOI. This article is (C) Elsevier and permission has been granted for this version to appear in e-Publications@Marquette. Elsevier does not grant permission for this article to be further copied/distributed or hosted elsewhere without the express permission from Elsevier. 
(3) Denial Rate from FFIEC HMDA data on individual mortgages in 2004.

(4) Census tract characteristics from 2000 Census.

(5) Miles from CBD calculated as the straight-line distance between the center of the census tract and the tallest building in the MSA.

(6) Median Income in tens of thousands of dollars.

(7) Median Home Value in hundreds of thousands of dollars.

(8) Coefficients reported as $<0.0001$ indicate a coefficient between 0 and

0.0001 . Coefficients reported as $>-0.0001$ indicate a coefficient between

-0.0001 and 0 .

Table 7 reports estimates for individual cities representative of newer, fast-growing, sun-belt areas; Atlanta and Phoenix. The $\beta_{1}$ coefficients for both Atlanta and Phoenix have the same negative sign as the full sample of cities estimated jointly, as well as Chicago, Detroit, and Cleveland. The magnitude of $\beta_{1}$ for Atlanta is ten times larger than the full sample estimate, while $\beta_{1}$ for Phoenix is seven times larger than the full sample. Although the estimate for Phoenix is large, it is not statistically different than zero or the full sample estimates (the standard error is the same size as the coefficient estimate). The second order effect captured by $\beta_{2}$ is positive and significant for Atlanta but insignificant for Phoenix. In Atlanta, the percentage of mortgages denied eventually begins to increase with distance when far enough away from the CBD. Combining the first order and second order effects of Milesi for Atlanta indicates that moving 10 miles from the CBD lowers the mortgage denial rate by 0.8 percentage points, or $8 \%$ at the mean of 0.010 . Panel $\mathrm{C}$ of Fig. 2 displays the relationship between the percentage of mortgages that are denied and distance to CBD for Atlanta and Phoenix graphically using the estimated $\beta_{1}$ and $\beta_{2}$ coefficients. The lowest percentage of mortgage denials occurs at about 32 miles from the CBD in Atlanta.

Table 7. Mortgage denial rate and distance to city center, select growing cities.

\begin{tabular}{|c|c|c|c|}
\hline & $\begin{array}{c}(1) \\
\text { All cities }\end{array}$ & $\begin{array}{c}\text { (2) } \\
\text { Atlanta }\end{array}$ & $\begin{array}{c}\text { (3) } \\
\text { Phoenix }\end{array}$ \\
\hline Distance from CBD (in miles) & $\begin{array}{l}-0.0001^{* *} \\
(0.0000)\end{array}$ & $\begin{array}{l}-0.0010^{* * *} \\
(0.0003)\end{array}$ & $\begin{array}{l}-0.0007 \\
(0.0007)\end{array}$ \\
\hline Distance from $\mathrm{CBD}^{2}$ & $\begin{array}{l}<0.0001^{* * *} \\
(0.0000)\end{array}$ & $\begin{array}{l}<0.0001^{* * *} \\
(0.0000)\end{array}$ & $\begin{array}{l}<0.0001^{*} \\
(0.0000)\end{array}$ \\
\hline Median income & $-0.0007^{* * *}$ & -0.0015 & 0.0001 \\
\hline
\end{tabular}

Regional Science and Urban Economics, Vol 42, No. 1-2 (January 2012): pg. 63-77. DOI. This article is @ Elsevier and permission has been granted for this version to appear in e-Publications@Marquette. Elsevier does not grant permission for this article to be further copied/distributed or hosted elsewhere without the express permission from Elsevier. 
NOT THE PUBLISHED VERSION; this is the author's final, peer-reviewed manuscript. The published version may be accessed by following the link in the citation at the bottom of the page.

\begin{tabular}{|c|c|c|c|}
\hline & $\begin{array}{c}\mathbf{( 1 )} \\
\text { All cities } \\
(0.0001)\end{array}$ & $\begin{array}{c}\mathbf{( 2 )} \\
\text { Atlanta } \\
(0.0011)\end{array}$ & $\begin{array}{c}\mathbf{( 3 )} \\
\text { Phoenix } \\
(0.0025)\end{array}$ \\
\hline \multirow[t]{2}{*}{ Vacant units (as\% of total) } & 0.0000 & -0.0001 & 0.0001 \\
\hline & 0.0000 & $(0.0002)$ & $(0.0003)$ \\
\hline \multirow[t]{2}{*}{ Median home value } & $0.0016^{* * *}$ & 0.0012 & -0.0082 \\
\hline & $(0.0002)$ & $(0.0029)$ & $(0.0060)$ \\
\hline \multirow[t]{2}{*}{ Employment rate } & $-0.0109^{* * *}$ & $-0.0229^{*}$ & -0.0106 \\
\hline & $(0.0014)$ & $(0.0138)$ & $(0.0158)$ \\
\hline \multirow[t]{2}{*}{ College educated (as $\%$ of total) } & -0.0011 & 0.0020 & 0.0288 \\
\hline & $(0.0013)$ & $(0.0138)$ & $(0.0301)$ \\
\hline \multirow[t]{2}{*}{ Non-white residents (as $\%$ of total) } & $0.0039^{* * *}$ & -0.0064 & 0.0126 \\
\hline & $(0.0005)$ & $(0.0060)$ & $(0.0090)$ \\
\hline \multirow[t]{2}{*}{ New residents (as\% of total) } & $-0.0067^{* * *}$ & -0.0058 & $0.0272^{*}$ \\
\hline & $(0.0008)$ & $(0.0069)$ & $(0.0146)$ \\
\hline \multirow[t]{2}{*}{ Average commute time } & $-0.0001^{* * *}$ & 0.0004 & -0.0002 \\
\hline & $(0.0000)$ & $(0.0002)$ & $(0.0005)$ \\
\hline $\mathrm{N}$ & 51567 & 823 & 692 \\
\hline Adjusted $\mathrm{R}^{2}$ & 0.0153 & 0.065 & 0.041 \\
\hline
\end{tabular}

Notes:

(1) All regressions are estimated with a constant and include a set of dummy variables for direction from CBD (SW direction omitted).

(2) All regressions include only census tracts within 70 miles of the city center.

(3) Denial Rate from FFIEC HMDA data on individual mortgages in 2004.

(4) Census tract characteristics from 2000 Census.

(5) Miles from CBD calculated as the straight-line distance between the center of the census tract and the tallest building in the MSA.

(6) Median Income in tens of thousands of dollars.

(7) Median Home Value in hundreds of thousands of dollars.

(8) Coefficients reported as $<0.0001$ indicate a coefficient between 0 and

0.0001 . Coefficients reported as $>-0.0001$ indicate a coefficient between

-0.0001 and 0 .

$* *$ Indicates statistically significant at $5 \%$ level.

$* * *$ Indicates statistically significant at $1 \%$ level.

$*$ Indicates statistically significant at $10 \%$ level.

Table 8 presents the distance-denials coefficient estimates for each of the 100 largest MSAs individually. ${ }^{9}$ Overall, 13 MSA's exhibit a statistically significant mortgage denial rate trough within the sample (70 miles), including Los Angeles, Boston, San Diego, Kansas City, Salt Lake City, and Sarasota. The mortgage denial rate trough for most of these MSAs occurs between 30 and 40 miles from the CBD. Notable

Regional Science and Urban Economics, Vol 42, No. 1-2 (January 2012): pg. 63-77. DOI. This article is (C) Elsevier and permission has been granted for this version to appear in e-Publications@Marquette. Elsevier does not grant permission for this article to be further copied/distributed or hosted elsewhere without the express permission from Elsevier. 
NOT THE PUBLISHED VERSION; this is the author's final, peer-reviewed manuscript. The published version may be accessed by following the link in the citation at the bottom of the page.

exceptions are Sarasota, about 9 miles from the city center, and Colorado Springs, about 18 miles.

Table 8. Coefficient estimates of loan denial rate and distance to city center, all cities.

\begin{tabular}{|c|c|c|c|c|c|c|c|}
\hline $\begin{array}{l}\text { Metropolitan } \\
\text { area }\end{array}$ & $\begin{array}{l}\text { Distance } \\
\text { from CBD }\end{array}$ & $\begin{array}{l}\text { Distance } \\
\text { FROM CBD }\end{array}$ & $\mathbf{N}$ & $\begin{array}{l}\text { Adjusted } \\
\mathbf{R}^{\mathbf{2}}\end{array}$ & $\begin{array}{l}\text { Quadratic } \\
\text { peak } \\
\text { (trough) }\end{array}$ & $\begin{array}{l}\text { Non- } \\
\text { parametric } \\
\text { peak } \\
\text { (trough) }\end{array}$ & $\begin{array}{l}\text { Non- } \\
\text { parametric } \\
\text { 2nd } \\
\text { peak(trough) }\end{array}$ \\
\hline New York, NY & 0.0001 & $>-0.0001$ & 4503 & 0.006 & 33.91 & 15.19 & \\
\hline $\begin{array}{l}\text { Los Angeles, } \\
\text { CA }\end{array}$ & $-0.0008^{* * *}$ & $<0.0001^{* * *}$ & 3122 & 0.028 & $(37.80)$ & $(36.73)$ & \\
\hline Chicago, IL & $-0.0003^{* *}$ & $<0.0001^{* *}$ & 2024 & 0.017 & $(33.40)$ & 5.06 & $(36.34)$ \\
\hline $\begin{array}{l}\text { Washington- } \\
\text { Baltimore, } \\
\text { DC-MD\# }\end{array}$ & 0.0001 & $>-0.0001$ & 1754 & 0.011 & 21.59 & (17.69) & 46.58 \\
\hline $\begin{array}{l}\text { San } \\
\text { Francisco- } \\
\text { San Jose, CA }\end{array}$ & $0.0006^{*}$ & $>-0.0001^{* *}$ & 1496 & 0.029 & 25.86 & $(2.90)$ & 20.33 \\
\hline $\begin{array}{l}\text { Philadelphia, } \\
\text { PA }\end{array}$ & $>-0.0001$ & $<0.0001$ & 1573 & 0.012 & $(23.82)$ & $(16.45)$ & 22.37 \\
\hline Boston, MA & $-0.0003^{*}$ & $<0.0001^{*}$ & 1071 & 0.014 & $(30.59)$ & $(40.06)$ & \\
\hline Detroit, MI & -0.0003 & $<0.0001$ & 1277 & 0.017 & $(22.33)$ & $(30.47)$ & \\
\hline $\begin{array}{l}\text { Dallas-Fort } \\
\text { Worth, TX" }\end{array}$ & $<0.0001$ & $>-0.0001$ & 1423 & 0.011 & 118.14 & $(12.99)$ & 107.45 \\
\hline Houston, TX & 0.0002 & $>-0.0001$ & 932 & 0.01 & 29.25 & $(2.61)$ & 9.33 \\
\hline Atlanta, GA & $-0.0010^{* * *}$ & $<0.0001^{* * *}$ & 823 & 0.065 & $(31.57)$ & $(21.93)$ & \\
\hline Miami, FL & $<0.0001$ & $>-0.0001$ & 585 & 0.033 & 4.54 & 4.08 & $(11.70)$ \\
\hline Seattle, WA & $<0.0001$ & $>-0.0001$ & 845 & 0.013 & 11.06 & 3.97 & $(18.09)$ \\
\hline Phoenix, AZ & -0.0007 & $<0.0001^{*}$ & 692 & 0.041 & $(15.02)$ & $(12.87)$ & \\
\hline $\begin{array}{l}\text { Minneapolis- } \\
\text { St. Paul, MN" }\end{array}$ & $<0.0001$ & $>-0.0001$ & 1151 & 0.018 & 161.32 & $(20.72)$ & 154.67 \\
\hline Cleveland, $\mathrm{OH}$ & -0.0001 & $<0.0001$ & 727 & 0.029 & $(17.54)$ & $(16.73)$ & 32.8 \\
\hline $\begin{array}{l}\text { San Diego, } \\
\text { CA }\end{array}$ & $-0.0006^{* *}$ & $<0.0001^{* *}$ & 691 & 0.056 & $(35.92)$ & $(41.73)$ & \\
\hline St. Louis, MO & $-0.0003^{*}$ & $<0.0001^{* *}$ & 619 & 0.026 & $(31.57)$ & $(23.18)$ & \\
\hline Denver, CO & $<0.0001$ & $<0.0001$ & 689 & 0.037 & NA & $(9.82)$ & \\
\hline Tampa, FL & -0.0004 & $<0.0001$ & 524 & 0.051 & $(32.92)$ & $(17.44)$ & 42.17 \\
\hline Pittsburgh, PA & -0.0001 & $<0.0001$ & 913 & 0.014 & $(24.47)$ & 5.61 & $(12.14)$ \\
\hline Portland, OR & $>-0.0001$ & $<0.0001$ & 552 & 0.053 & $(25.00)$ & $(10.61)$ & 47.29 \\
\hline $\begin{array}{l}\text { Cincinnati, } \\
\mathrm{OH}\end{array}$ & $-0.0006^{*}$ & $<0.0001^{* *}$ & 369 & 0.088 & $(22.5)$ & $(17.11)$ & \\
\hline $\begin{array}{l}\text { Sacramento, } \\
\text { CA }\end{array}$ & -0.0002 & $<0.0001$ & 474 & 0.053 & $(12.90)$ & $(14.40)$ & \\
\hline
\end{tabular}

Regional Science and Urban Economics, Vol 42, No. 1-2 (January 2012): pg. 63-77. DOI. This article is (C) Elsevier and permission has been granted for this version to appear in e-Publications@Marquette. Elsevier does not grant permission for this article to be further copied/distributed or hosted elsewhere without the express permission from Elsevier. 
NOT THE PUBLISHED VERSION; this is the author's final, peer-reviewed manuscript. The published version may be accessed by following the link in the citation at the bottom of the page.

\begin{tabular}{|c|c|c|c|c|c|c|c|}
\hline $\begin{array}{l}\text { Metropolitan } \\
\text { area }\end{array}$ & $\begin{array}{l}\text { Distance } \\
\text { from CBD }\end{array}$ & $\begin{array}{l}\text { Distance } \\
\text { FROM CBD } 2\end{array}$ & $\mathbf{N}$ & $\begin{array}{l}\text { Adjusted } \\
\mathbf{R}^{\mathbf{2}}\end{array}$ & $\begin{array}{l}\text { Quadratic } \\
\text { peak } \\
\text { (trough) }\end{array}$ & $\begin{array}{l}\text { Non- } \\
\text { parametric } \\
\text { peak } \\
\text { (trough) }\end{array}$ & $\begin{array}{l}\text { Non- } \\
\text { parametric } \\
\text { 2nd } \\
\text { peak(trough) }\end{array}$ \\
\hline $\begin{array}{l}\text { Kansas City, } \\
\text { MO }\end{array}$ & $-0.0005^{*}$ & $<0.0001^{*}$ & 621 & 0.027 & $(33.18)$ & $(16.43)$ & \\
\hline $\begin{array}{l}\text { Milwaukee, } \\
\text { WI }\end{array}$ & $>-0.0001$ & $<0.0001$ & 601 & 0.046 & $(82.94)$ & $(8.86)$ & 39.29 \\
\hline Orlando, FL & -0.0005 & $<0.0001$ & 384 & 0.046 & $(37.56)$ & $(11.74)$ & \\
\hline $\begin{array}{l}\text { Indianapolis, } \\
\text { IN }\end{array}$ & 0.0001 & $>-0.0001$ & 568 & 0.012 & 28.60 & $(7.31)$ & 39.22 \\
\hline $\begin{array}{l}\text { San Antonio, } \\
\text { TX }\end{array}$ & -0.0003 & $<0.0001$ & 362 & 0.062 & (211.79) & (Edge) & \\
\hline Norfolk, VA & $>-0.0001$ & $<0.0001$ & 409 & 0.024 & $(45.59)$ & $(12.33)$ & 40.65 \\
\hline $\begin{array}{l}\text { Las Vegas, } \\
\text { NV }\end{array}$ & -0.0004 & $<0.0001^{* *}$ & 344 & 0.16 & (19.99) & Edge & \\
\hline $\begin{array}{l}\text { Columbus, } \\
\mathrm{OH}\end{array}$ & 0.0002 & $>-0.0001$ & 552 & 0.032 & 38.04 & $(6.15)$ & 38.46 \\
\hline Charlotte, NC & 0.0001 & $>-0.0001$ & 449 & 0.015 & 20.25 & $(7.85)$ & 39.01 \\
\hline $\begin{array}{l}\text { New Orleans, } \\
\text { LA }\end{array}$ & $-0.0005^{* *}$ & $<0.0001^{*}$ & 474 & 0.047 & $(34.57)$ & $(12.07)$ & \\
\hline $\begin{array}{l}\text { Salt Lake } \\
\text { City, UT }\end{array}$ & $-0.0004^{* * *}$ & $<0.0001^{* *}$ & 412 & 0.041 & $(34.73)$ & $(28.57)$ & \\
\hline $\begin{array}{l}\text { Greensboro, } \\
\text { NC }\end{array}$ & -0.0001 & $<0.0001$ & 383 & 0.033 & $(41.32)$ & $(9.05)$ & 49.05 \\
\hline Austin, TX & $0.0004^{* *}$ & $>-0.0001$ & 356 & 0.082 & 58.77 & 57.82 & \\
\hline Nashville, TN & 0.0002 & $>-0.0001$ & 360 & 0.044 & 58.70 & $(11.20)$ & 58.54 \\
\hline $\begin{array}{l}\text { Providence, } \\
\text { RI }\end{array}$ & 0.0002 & $>-0.0001$ & 521 & 0.012 & 40 & 21.76 & \\
\hline Raleigh, NC & -0.0003 & $<0.0001^{* *}$ & 427 & 0.048 & $(23.47)$ & Edge & \\
\hline Hartford, CT & 0.0005 & $>-0.0001$ & 728 & 0.043 & 38.17 & $(23.16)$ & 38.94 \\
\hline Buffalo, NY & $>-0.0001$ & $<0.0001$ & 390 & 0.017 & $(10.10)$ & (16.39) & \\
\hline Memphis, TN & 0.0004 & $>-0.0001$ & 400 & 0.065 & 37.69 & $(8.81)$ & 58.28 \\
\hline $\begin{array}{l}\text { West Palm } \\
\text { Beach, FL }\end{array}$ & -0.0005 & $<0.0001$ & 364 & 0.058 & $(25.35)$ & $(15.70)$ & \\
\hline $\begin{array}{l}\text { Jacksonville, } \\
\text { FL }\end{array}$ & -0.0002 & $<0.0001$ & 298 & 0.023 & $(124.60)$ & $(27.34)$ & \\
\hline Rochester, NY & 0.0002 & $>-0.0001$ & 293 & 0.036 & 111.96 & $(9.68)$ & \\
\hline $\begin{array}{l}\text { Grand Rapids, } \\
\text { MI }\end{array}$ & 0.0002 & $>-0.0001$ & 269 & 0.056 & 27.78 & $(7.28)$ & 37.42 \\
\hline $\begin{array}{l}\text { Oklahoma } \\
\text { City, OK }\end{array}$ & $0.0004^{*}$ & $>-0.0001^{* *}$ & 426 & 0.046 & 28.62 & $(11.05)$ & 38.71 \\
\hline Louisville, KY & $<0.0001$ & $<0.0001$ & 100 & 0.102 & NA & $(11.82)$ & \\
\hline Richmond, VA & -0.0003 & $<0.0001$ & 338 & 0.049 & $(35.04)$ & $(18.42)$ & \\
\hline Greenville, SC & -0.0002 & $<0.0001$ & 352 & 0.06 & $(14.22)$ & Edge & \\
\hline Dayton, $\mathrm{OH}$ & -0.0002 & $<0.0001$ & 408 & 0.043 & $(24.04)$ & (15.69) & \\
\hline
\end{tabular}

Regional Science and Urban Economics, Vol 42, No. 1-2 (January 2012): pg. 63-77. DOI. This article is @ Elsevier and permission has been granted for this version to appear in e-Publications@Marquette. Elsevier does not grant permission for this article to be further copied/distributed or hosted elsewhere without the express permission from Elsevier. 
NOT THE PUBLISHED VERSION; this is the author's final, peer-reviewed manuscript. The published version may be accessed by following the link in the citation at the bottom of the page.

\begin{tabular}{|c|c|c|c|c|c|c|c|}
\hline $\begin{array}{l}\text { Metropolitan } \\
\text { area }\end{array}$ & $\begin{array}{l}\text { Distance } \\
\text { from CBD }\end{array}$ & $\begin{array}{l}\text { Distance } \\
\text { FROM CBD }\end{array}$ & $\mathbf{N}$ & $\begin{array}{l}\text { Adjusted } \\
\mathbf{R}^{\mathbf{2}}\end{array}$ & $\begin{array}{l}\text { Quadratic } \\
\text { peak } \\
\text { (trough) }\end{array}$ & $\begin{array}{l}\text { Non- } \\
\text { parametric } \\
\text { peak } \\
\text { (trough) }\end{array}$ & $\begin{array}{l}\text { Non- } \\
\text { parametric } \\
\text { 2nd } \\
\text { peak(trough) }\end{array}$ \\
\hline Fresno, CA & -0.0010 & $<0.0001$ & 258 & 0.078 & $(27.90)$ & $(23.22)$ & \\
\hline $\begin{array}{l}\text { Birmingham, } \\
\text { AL }\end{array}$ & -0.0009 & $<0.0001$ & 461 & 0.385 & $(30.57)$ & $(10.45)$ & \\
\hline Albany, NY & 0.0003 & $>-0.0001$ & 433 & 0.025 & 51.58 & $(14.99)$ & 47.68 \\
\hline Tucson, AZ & $<0.0001$ & $<0.0001$ & 223 & 0.128 & NA & $(8.67)$ & \\
\hline Tulsa, OK & $-0.0004^{*}$ & $<0.0001^{* *}$ & 348 & 0.038 & $(29.88)$ & (17.09) & \\
\hline Syracuse, NY & -0.0003 & $<0.0001$ & 386 & 0.039 & $(43.31)$ & $(23.49)$ & \\
\hline Omaha, NE & -0.0001 & $<0.0001$ & 358 & 0.062 & $(22.83)$ & $(9.85)$ & \\
\hline $\begin{array}{l}\text { Albuquerque, } \\
\text { NM }\end{array}$ & 0.0003 & $>-0.0001$ & 238 & 0.074 & 39.10 & $(8.76)$ & 41.4 \\
\hline Knoxville, TN & -0.0001 & $>-0.0001$ & 262 & 0.043 & NA & 52.12 & \\
\hline El Paso, TX & -0.0003 & $<0.0001$ & 162 & 0.055 & $(73.47)$ & $(8.94)$ & 38.17 \\
\hline $\begin{array}{l}\text { Bakersfield, } \\
\text { CA }\end{array}$ & -0.0002 & $<0.0001$ & 167 & 0.101 & $(52.66)$ & 38.40 & \\
\hline Allentown, PA & 0.0002 & $>-0.0001$ & 335 & 0.098 & 21.41 & (Edge) & \\
\hline $\begin{array}{l}\text { Harrisburg, } \\
\text { PA }\end{array}$ & -0.0001 & $<0.0001$ & 366 & 0.02 & $(231.25)$ & 3.64 & $(17.84)$ \\
\hline Scranton, PA & -0.0004 & $<0.0001^{*}$ & 319 & 0.065 & $(25.16)$ & $(14.48)$ & \\
\hline Toledo, $\mathrm{OH}$ & -0.0001 & $<0.0001$ & 375 & 0.013 & $(26.02)$ & $(22.42)$ & 40.88 \\
\hline $\begin{array}{l}\text { Baton Rouge, } \\
\text { LA }\end{array}$ & 0.0005 & $>-0.0001$ & 302 & 0.043 & 41.13 & $(9.80)$ & \\
\hline $\begin{array}{l}\text { Youngstown, } \\
\mathrm{OH}\end{array}$ & -0.0003 & $<0.0001$ & 318 & 0.017 & $(35.62)$ & $(44.16)$ & \\
\hline $\begin{array}{l}\text { Springfield, } \\
\text { MA }\end{array}$ & -0.0003 & $<0.0001^{*}$ & 239 & 0.043 & $(23.08)$ & Edge & \\
\hline Sarasota, FL & $-0.0017^{* *}$ & $<0.0001^{* * *}$ & 149 & 0.397 & $(9.22)$ & Edge & \\
\hline $\begin{array}{l}\text { Little Rock, } \\
\text { AR }\end{array}$ & $0.0016^{*}$ & $>-0.0001^{*}$ & 267 & 0.122 & 39.61 & $(11.56)$ & 41.32 \\
\hline McAllen, TX & 0.0004 & $>-0.0001$ & 188 & 0.085 & 30.81 & 21.29 & \\
\hline Stockton, CA & 0.0012 & $>-0.0001$ & 151 & 0.172 & 206.41 & $(47.65)$ & \\
\hline $\begin{array}{l}\text { Charleston, } \\
\text { SC }\end{array}$ & 0.0004 & $>-0.0001$ & 177 & 0.091 & 24.83 & $(22.67)$ & 51.34 \\
\hline Wichita, KS & $<0.0001$ & $<0.0001$ & 210 & 0.054 & NA & $(7.83)$ & \\
\hline Mobile, AL & $-0.0024^{*}$ & $<0.0001$ & 217 & 0.313 & $(52.86)$ & (Edge) & \\
\hline Columbia, SC & 0.0004 & $>-0.0001$ & 224 & 0.098 & 36.41 & $(3.15)$ & 36.44 \\
\hline $\begin{array}{l}\text { Colorado } \\
\text { Springs, CO }\end{array}$ & $-0.0013^{* *}$ & $<0.0001^{* * *}$ & 188 & 0.116 & (17.95) & $(10.05)$ & \\
\hline $\begin{array}{l}\text { Fort Wayne, } \\
\text { IN }\end{array}$ & -0.0001 & $<0.0001$ & 274 & 0.07 & $(22.61)$ & $(5.19)$ & \\
\hline $\begin{array}{l}\text { Daytona } \\
\text { Beach, FL }\end{array}$ & 0.0004 & $>-0.0001$ & 88 & 0.101 & 21.06 & $(14.31)$ & 43.74 \\
\hline Lakeland, FL & -0.0001 & $<0.0001$ & 171 & 0.037 & $(12.80)$ & $(5.10)$ & \\
\hline
\end{tabular}

Regional Science and Urban Economics, Vol 42, No. 1-2 (January 2012): pg. 63-77. DOI. This article is @ Elsevier and permission has been granted for this version to appear in e-Publications@Marquette. Elsevier does not grant permission for this article to be further copied/distributed or hosted elsewhere without the express permission from Elsevier. 
NOT THE PUBLISHED VERSION; this is the author's final, peer-reviewed manuscript. The published version may be accessed by following the link in the citation at the bottom of the page.

\begin{tabular}{|c|c|c|c|c|c|c|c|}
\hline $\begin{array}{l}\text { Metropolitan } \\
\text { area }\end{array}$ & $\begin{array}{l}\text { Distance } \\
\text { from CBD }\end{array}$ & $\begin{array}{l}\text { Distance } \\
\text { FROM CBD }\end{array}$ & $\mathbf{N}$ & $\begin{array}{l}\text { Adjusted } \\
\mathbf{R}^{2}\end{array}$ & $\begin{array}{l}\text { Quadratic } \\
\text { peak } \\
\text { (trough) }\end{array}$ & $\begin{array}{l}\text { Non- } \\
\text { parametric } \\
\text { peak } \\
\text { (trough) }\end{array}$ & $\begin{array}{l}\text { Non- } \\
\text { parametric } \\
\text { 2nd } \\
\text { peak(trough) }\end{array}$ \\
\hline $\begin{array}{l}\text { Johnson City, } \\
\text { TN }\end{array}$ & -0.0007 & $<0.0001$ & 259 & 0.079 & $(25.72)$ & Edge & \\
\hline Lexington, KY & No data & & & & & & \\
\hline Augusta, GA & 0.0010 & $>-0.0001^{*}$ & 162 & 0.133 & 29.21 & $(8.61)$ & 38.98 \\
\hline Melbourne, FL & 0.0007 & $>-0.0001$ & 131 & 0.176 & 35.74 & $(6.21)$ & 33.58 \\
\hline Lancaster, PA & -0.0002 & $<0.0001$ & 274 & 0.045 & $(16.12)$ & $(18.25)$ & \\
\hline $\begin{array}{l}\text { Chattanooga, } \\
\text { TN }\end{array}$ & 0.0006 & $>-0.0001$ & 279 & 0.422 & 47.25 & $(4.55)$ & \\
\hline $\begin{array}{l}\text { Des Moines, } \\
\text { IA }\end{array}$ & 0.0001 & $<0.0001$ & 230 & 0.068 & NA & $(24.82)$ & \\
\hline $\begin{array}{l}\text { Kalamazoo, } \\
\text { MI }\end{array}$ & 0.0003 & $>-0.0001$ & 306 & 0.104 & 41.64 & 58.87 & \\
\hline Lansing, MI & 0.0002 & $>-0.0001$ & 241 & 0.019 & 35.40 & 44.84 & \\
\hline Modesto, CA & -0.0006 & $<0.0001^{*}$ & 158 & 0.11 & $(17.76)$ & $(3.63)$ & \\
\hline $\begin{array}{l}\text { Fort Myers, } \\
\text { FL }\end{array}$ & -0.0001 & $<0.0001$ & 203 & 0.062 & $(21.69)$ & $(19.16)$ & \\
\hline Jackson, MS & 0.0001 & $>-0.0001$ & 211 & 0.047 & 29.44 & Edge & \\
\hline Boise City, ID & 0.0002 & $>-0.0001$ & 95 & 0.08 & 30.34 & $(5.88)$ & 14.28 \\
\hline Madison, WI & -0.0001 & $<0.0001$ & 349 & 0.043 & $(44.57)$ & 63.30 & \\
\hline Spokane, WA & -0.0001 & $<0.0001$ & 171 & 0.037 & $(15.91)$ & 7.44 & \\
\hline Pensacola, FL & $0.0036^{* * *}$ & $>-0.0001^{* *}$ & 134 & 0.556 & 36.83 & $(4.93)$ & \\
\hline Canton, $\mathrm{OH}$ & -0.0001 & $<0.0001$ & 339 & 0.024 & $(19.72)$ & $(11.25)$ & \\
\hline Saginaw, MI & 0.0001 & $<0.0001$ & 332 & 0.025 & NA & $(16.24)$ & \\
\hline
\end{tabular}

(1) All regressions are estimated with a constant term and control for median income, percentage of vacant units, median home value, employment rate, percentage of college educated adults, percentage of non-white residents, percentage of new residents, average commute time, and a set of dummy variables for direction from the CBD (SW direction omitted).

(2) All regressions include only census tracts within 70 miles of the city center calculated by the straight-line distance between the center of the census tract and the tallest building in the MSA.

(3) Mortgage Denial Rate from FFIEC HMDA data on individual mortgages in 2004.

(4) Peak (Trough) estimates are calculated as the maximum of the equation Denial Rate $=b_{1}$ (miles) $+b_{2}\left(\right.$ miles $\left.^{2}\right)$, or miles $=-b_{1} / 2 b_{2}$.

(5) Coefficients reported as $<0.0001$ indicate a coefficient between 0 and 0.0001 . Coefficients reported as $>-0.0001$ indicate a coefficient between -0.0001 and 0.

$* * *$ Indicates statistically significant at $1 \%$ level.

$* *$ Indicates statistically significant at $5 \%$ level.

*Indicates statistically significant at $10 \%$ level.

\#Indicates regression estimated with poly-centric model.

Regional Science and Urban Economics, Vol 42, No. 1-2 (January 2012): pg. 63-77. DOI. This article is (C) Elsevier and permission has been granted for this version to appear in e-Publications@Marquette. Elsevier does not grant permission for this article to be further copied/distributed or hosted elsewhere without the express permission from Elsevier. 
NOT THE PUBLISHED VERSION; this is the author's final, peer-reviewed manuscript. The published version may be accessed by following the link in the citation at the bottom of the page.

On the other hand, only 4 cities in our sample exhibit statistically significant increasing mortgage denial rates with distance from the CBD that eventually come to a peak within sample: San Francisco-San Jose, Oklahoma City, Little Rock, and Pensacola. The mortgage denial rate comes to a peak between 26 and 40 miles for these cities, with the extremes representing San Francisco-San Jose and Little Rock, respectively.

Relating these estimates to the theoretical predictions, 13 of the MSAs exhibit the increasing credit quality indicated by decreasing denial rates in the interior of the urban area, with decreasing credit quality further out; this is a spatial credit quality sorting pattern consistent with the DTQ behavior of credit constrained households in the interior of urban areas and households with unconstrained credit further out. Only 4 MSAs show patterns consistent with unconstrained households in the interior and credit constrained households towards the periphery.

How do the denial rate results relate to the debt-to-income ratio results? The general spatial sorting patterns for the two different measures yield contradictory significant conclusions for only 4 MSAs: Chicago, Boston, St. Louis, and New Orleans. Interestingly, all of these cities are similar in that the mortgage debt-to-income estimates imply that unconstrained households tend to live in the MSA interiors and credit-constrained households nearer the periphery while the mortgage denial rate estimates imply the opposite pattern.

To summarize, the point estimates show that most of the MSAs exhibit either rising mortgage debt-to-income ratios with distance consistent with credit constrained households, declining debt-toincome ratios consistent with unconstrained households, or initially declining then rising debt-to-income ratios consistent with unconstrained households in the MSA interior and credit constrained households in the suburbs. While casual observation suggests that older declining rust belt MSAs exhibit different patterns than newer growing sunbelt MSAs, it is not clear at this point whether or how these patterns relate to specific MSA characteristics.

Regional Science and Urban Economics, Vol 42, No. 1-2 (January 2012): pg. 63-77. DOI. This article is (C) Elsevier and permission has been granted for this version to appear in e-Publications@Marquette. Elsevier does not grant permission for this article to be further copied/distributed or hosted elsewhere without the express permission from Elsevier. 
NOT THE PUBLISHED VERSION; this is the author's final, peer-reviewed manuscript. The published version may be accessed by following the link in the citation at the bottom of the page.

\subsection{Robustness analysis}

Relying on a quadratic specification to represent the relationship between credit characteristics and distance may be problematic if the true relationship is more complex. Indeed, there is a literature advocating the use of nonparametric techniques to describe the relationship between economic variables and space (Pavlov, 2000, McMillen, 2001 and McMillen, 2004). To assess the robustness of the quadratic specification in Eq. (10) we use a locally weighted regression method (often referred to as LOWESS or LOESS) first introduced by Cleveland (1979).

The locally weighted regression allows for a more flexible estimate of the relationship between credit characteristics and distance. The idea behind this estimation is to predict outcomes (credit characteristics) along the distance continuum using a series of regressions centered on each observation where nearby observations are given more weight in predicting the outcome. Plotting the locally weighted regression results shows how well the simple quadratic model captures the true relationship.

Fig. 3 depicts the locally weighted regression results of debt/income on distance from the CBD for the full sample and for select representative cities. The full sample results are quite similar to the quadratic model, showing a clear peaked pattern, although the shape is slightly distorted so that the peak occurs sooner than in the quadratic formulation. The growing cities (Phoenix and Atlanta) also show a pattern similar to the quadratic results, with the main difference being that Atlanta has a smaller peak that occurs closer to the city. The old, decaying cities show the same increasing debt/income with distance pattern closer to the CBD, but in the locally weighted regression results, debt/income remains high instead of coming to a unique peak as it does in the quadratic. The biggest difference in the locally weighted regression results is that New York now displays an increasing debt/income pattern closer to the CBD, a pattern not observed in the quadratic estimates.

Regional Science and Urban Economics, Vol 42, No. 1-2 (January 2012): pg. 63-77. DOI. This article is (C) Elsevier and permission has been granted for this version to appear in e-Publications@ Marquette. Elsevier does not grant permission for this article to be further copied/distributed or hosted elsewhere without the express permission from Elsevier. 


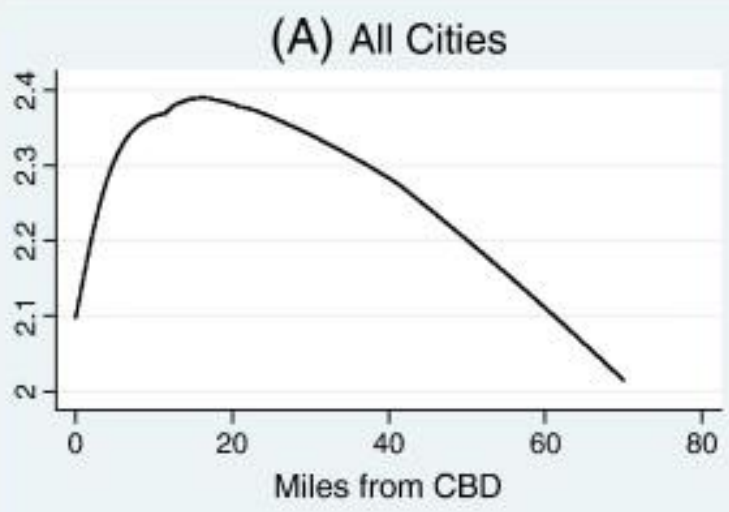

(C) Old, Decaying Cities

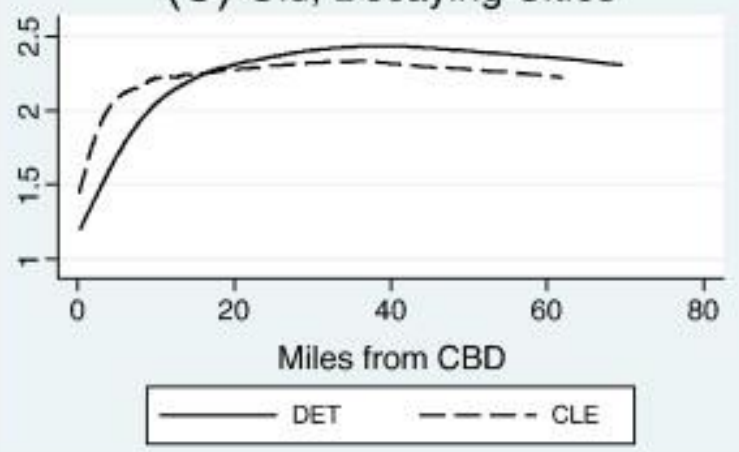

(B) Old, Large Cities

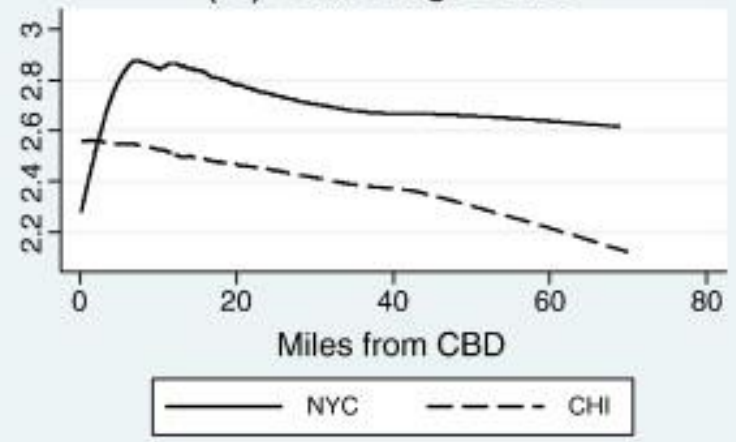

(D) Growing Cities

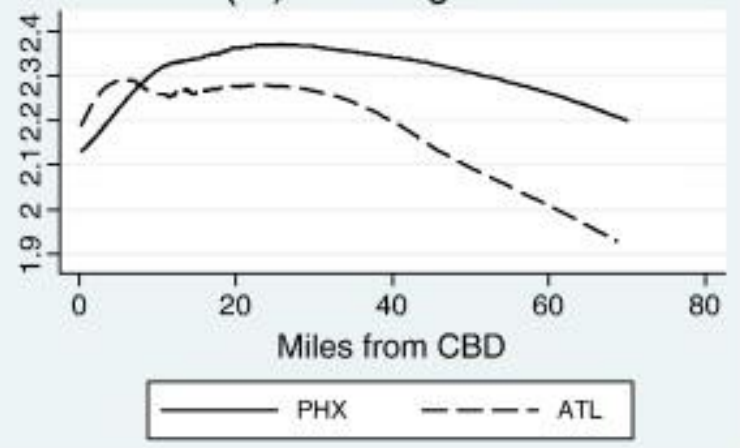

Fig. 3. LOWESS estimates of relationship between debt/income and miles to CBD.

To summarize the difference between quadratic and locally weighted regression methods for all cities in our sample, we estimated the location of the first and second peak (or trough) in the data, this information is summarized in the last two columns of Table 4. By far the most common difference between the methods is that the locally weighted regression identifies a smaller local peak in the data when the quadratic estimates only a trough. These small local peaks are in many cases followed by a larger trough shape that is consistent with the quadratic estimate.

The locally weighted regressions reveal there are more cities that exhibit patterns consistent with the unconstrained credit pricing model closer to the CBD, but also that the DTQ behavior begins to happen soon after the initial peaks and takes precedence throughout much of the urban area. A good example of this difference is the city of Boston, where the quadratic model estimates a statistically 
significant trough pattern. This implies that DTQ behavior starts immediately. The locally weighted regression reveals that in fact, debt/income ratios rise close to the CBD and quickly peak at about 4.5 miles from the city center. At this point DTQ behavior dominates and debt/income ratios fall.

Fig. 4 shows the locally weighted regression results of the denial rate on distance from the $\mathrm{CBD}$ for the full sample and for the select representative cities. Again, the full sample results using the locally weighted regression are quite similar to the quadratic estimatesshowing a clear trough pattern, although it is more pronounced in the locally weighted regression estimates. The old, decaying cities match the quadratic pattern quite well, except that the denial rate decreases faster near the CBD in Detroit. The growing cities also match the quadratic in terms of shape, but come to a trough sooner and increase faster under the locally weighted regression estimates. The most noticeable difference is in the Chicago estimates, where the locally weighted regression shows increasing denial rates near the CBD that later come to a trough.

(A) All Cities

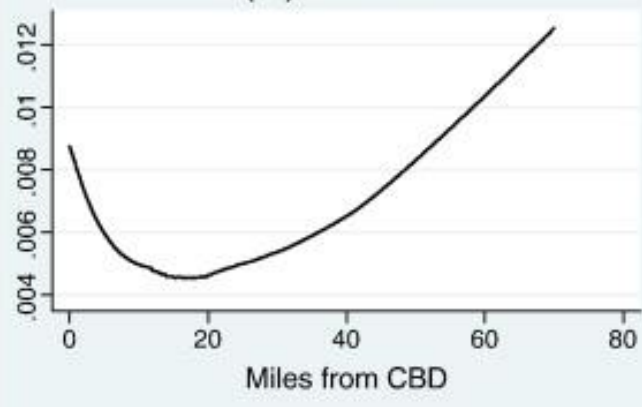

(C) Old, Decaying Cities

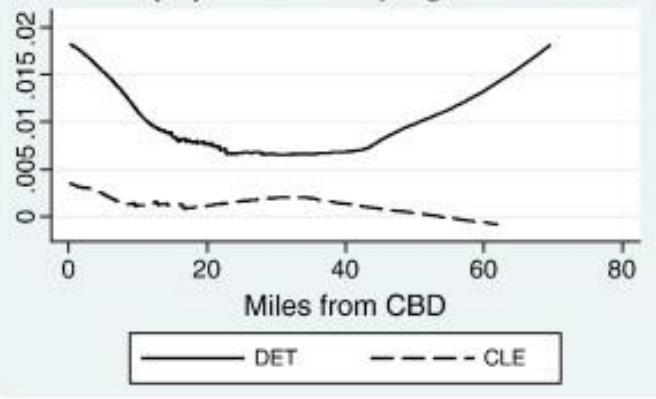

(B) Old, Large Cities

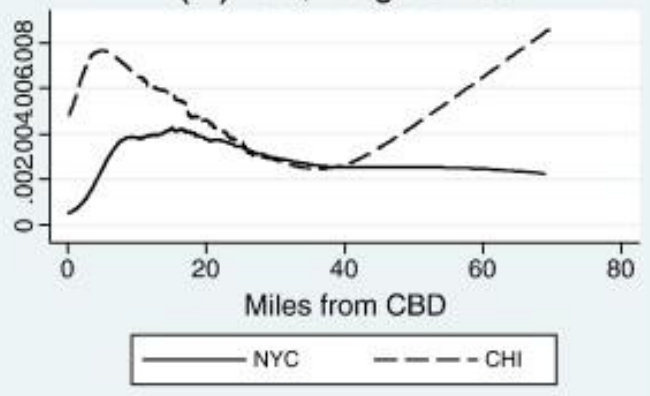

(D) Growing Cities

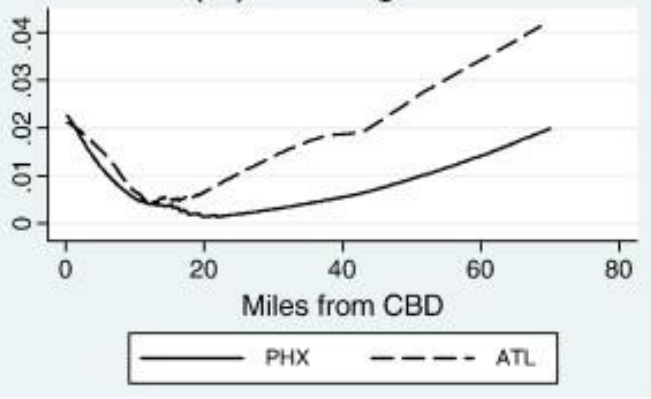

Fig. 4. LOWESS estimates of relationship between denials and miles to CBD.

Regional Science and Urban Economics, Vol 42, No. 1-2 (January 2012): pg. 63-77. DOI. This article is (C Elsevier and permission has been granted for this version to appear in e-Publications@Marquette. Elsevier does not grant permission for this article to be further copied/distributed or hosted elsewhere without the express permission from Elsevier. 
The final two columns of Table 8 summarize the locally weighted regression estimates by reporting where a first and second peak (or trough) occurs. Across cities, the denial rates change much more using the locally weighted regression than the debt/income results do. It appears that the most common change is for the locally weighted regression to estimate a trough pattern followed by a peak further outside of the city, whereas the quadratic estimates only a peak. There are also several areas where the quadratic model estimates a trough pattern, but the locally weighted regression estimates a peak pattern followed by a trough further outside of the city.

The final column of Table 9 shows estimates of where the maximum difference between debt/income and denial rate occurs comparing the quadratic estimates to the locally weighted regression results. Overall, the locally weighted regression results generally show the maximum to occur closer to the CBD than the quadratic results, which is not surprising given that we found debt/income peaking closer to the CBD.

Table 9. Distance where maximum debt/income-denial rate occurs.

\begin{tabular}{lll}
\multicolumn{1}{c}{ City } & \multicolumn{1}{c}{$\begin{array}{c}\text { Quadratic estimate miles } \\
\text { from CBD }\end{array}$} & \multicolumn{1}{c}{$\begin{array}{c}\text { Non-parametric estimate } \\
\text { miles from CBD }\end{array}$} \\
New York, NY & Out of sample & 7.11 \\
Los Angeles, CA & 12.39 & 25.45 \\
Chicago, IL & $54.79^{*}$ & 1.51 \\
Washington-Baltimore, & 37.69 & 32.14 \\
DC-MD" & & \\
San Francisco-San Jose, & Out of sample \\
CA & & 6.34 \\
Philadelphia, PA & Out of sample & \\
Boston, MA & $60.32^{*}$ & Edge \\
Detroit, MI & 33.66 & 4.47 \\
Dallas-Fort Worth, TX\# & 31.83 & 39.26 \\
Houston, TX & 4.24 & 6.79 \\
Atlanta, GA & $31.27^{*}$ & 9.57 \\
Miami, FL & 18.59 & 26.14 \\
Seattle, WA & 54.22 & Edge \\
Phoenix, AZ & 23.35 & CBD \\
Minneapolis-St. Paul, & Out of sample & 6.32 \\
MN & & 12.6 \\
Cleveland, OH & 23.95 & 36.94 \\
San Diego, CA & $31.90^{*}$ & 28.02 \\
& &
\end{tabular}

Regional Science and Urban Economics, Vol 42, No. 1-2 (January 2012): pg. 63-77. DOI. This article is @ Elsevier and permission has been granted for this version to appear in e-Publications@ Marquette. Elsevier does not grant permission for this article to be further copied/distributed or hosted elsewhere without the express permission from Elsevier. 
NOT THE PUBLISHED VERSION; this is the author's final, peer-reviewed manuscript. The published version may be accessed by following the link in the citation at the bottom of the page.

\section{City Quadratic estimate miles Non-parametric estimate from CBD miles from CBD}

\begin{tabular}{|c|c|c|}
\hline St. Louis, MO & Out of sample & 17.91 \\
\hline Denver, CO & 34.22 & 5.24 \\
\hline Tampa, FL & 21.81 & 41.99 \\
\hline Pittsburgh, PA & 24.25 & 30.2 \\
\hline Portland, OR & 35.04 & CBD \\
\hline Cincinnati, $\mathrm{OH}$ & 19.03 & 17.48 \\
\hline Sacramento, CA & 40.14 & 32.68 \\
\hline Kansas City, MO & $41.86^{*}$ & 21.7 \\
\hline Milwaukee, WI & 24.03 & 32.52 \\
\hline Orlando, FL & NA & 10.16 \\
\hline Indianapolis, IN & 9.05 & 10.04 \\
\hline San Antonio, TX & 25.19 & 29.17 \\
\hline Norfolk, VA & 16.15 & 12.09 \\
\hline Las Vegas, NV & 28.25 & 11.16 \\
\hline Columbus, $\mathrm{OH}$ & Out of sample & CBD \\
\hline Charlotte, NC & 12.43 & 19.03 \\
\hline New Orleans, LA & $65.42^{*}$ & 5.89 \\
\hline Salt Lake City, UT & 11.23 & 67.42 \\
\hline Greensboro, NC & 10.96 & 3.82 \\
\hline Austin, TX & 46.08 & 41.24 \\
\hline Nashville, TN & 22.84 & 11.2 \\
\hline Providence, RI & 26.82 & 61.15 \\
\hline Raleigh, NC & 30.11 & CBD \\
\hline Hartford, CT & NA & 48.74 \\
\hline Buffalo, NY & 29.45 & 14.61 \\
\hline Memphis, TN & 26.50 & 20.98 \\
\hline West Palm Beach, FL & 12.45 & 13.26 \\
\hline Jacksonville, FL & 32.29 & 12.37 \\
\hline Rochester, NY & 39.11 & 11.59 \\
\hline Grand Rapids, MI & 57.76 & CBD \\
\hline Oklahoma City, OK & $43.76^{*}$ & 10.82 \\
\hline Louisville, KY & Out of sample & 12.27 \\
\hline Richmond, VA & 53.98 & 40.15 \\
\hline Greenville, SC & 33.77 & 23.71 \\
\hline Dayton, OH & 30.21 & 22.17 \\
\hline Fresno, CA & 26.56 & 62.87 \\
\hline Birmingham, AL & 9.51 & 6.35 \\
\hline Albany, NY & 45.86 & 49.51 \\
\hline Tucson, AZ & 27.41 & 16.09 \\
\hline Tulsa, OK & NA & 9.35 \\
\hline Syracuse, NY & 24.95 & Edge \\
\hline
\end{tabular}

Regional Science and Urban Economics, Vol 42, No. 1-2 (January 2012): pg. 63-77. DOI. This article is (C) Elsevier and permission has been granted for this version to appear in e-Publications@Marquette. Elsevier does not grant permission for this article to be further copied/distributed or hosted elsewhere without the express permission from Elsevier. 
NOT THE PUBLISHED VERSION; this is the author's final, peer-reviewed manuscript. The published version may be accessed by following the link in the citation at the bottom of the page.

City Quadratic estimate miles Non-parametric estimate from CBD miles from CBD

\begin{tabular}{|c|c|c|}
\hline Omaha, NE & 33.97 & 11.8 \\
\hline Albuquerque, NM & 28.33 & Edge \\
\hline Knoxville, TN & 8.08 & 18.96 \\
\hline El Paso, TX & 32.82 & 29.38 \\
\hline Bakersfield, CA & 21.83 & Edge \\
\hline Allentown, PA & NA & 54.91 \\
\hline Harrisburg, PA & 3.15 & Edge \\
\hline Scranton, PA & NA & CBD \\
\hline Toledo, $\mathrm{OH}$ & NA & 21.09 \\
\hline Baton Rouge, LA & 19.54 & 5.53 \\
\hline Youngstown, $\mathrm{OH}$ & 21.51 & 35.02 \\
\hline Springfield, MA & 42.99 & 38.57 \\
\hline Sarasota, FL & $18.68 *$ & 23.13 \\
\hline Little Rock, AR & NA & 11.56 \\
\hline McAllen, TX & 48.44 & 51.23 \\
\hline Stockton, CA & 20.76 & 18.64 \\
\hline Charleston, SC & NA & CBD \\
\hline Wichita, KS & NA & CBD \\
\hline Mobile, AL & 38.18 & 20.98 \\
\hline Columbia, SC & 36.90 & 12.46 \\
\hline Colorado Springs, CO & NA & 8.78 \\
\hline Fort Wayne, IN & NA & 23.84 \\
\hline Daytona Beach, FL & NA & 18.78 \\
\hline Lakeland, FL & Out of sample & 9.05 \\
\hline Johnson City, TN & 39.40 & 32.06 \\
\hline Lexington, $\mathrm{KY}$ & No data & \\
\hline Augusta, GA & NA & 12.81 \\
\hline Melbourne, FL & 49.29 & 6.21 \\
\hline Lancaster, PA & 2.48 & 15.11 \\
\hline Chattanooga, TN & 18.41 & 24.63 \\
\hline Des Moines, IA & Out of sample & 3.72 \\
\hline Kalamazoo, MI & 56.96 & 25.63 \\
\hline Lansing, MI & 12.78 & 45.14 \\
\hline Modesto, CA & NA & Edge \\
\hline Fort Myers, FL & Out of sample & 58.82 \\
\hline Jackson, MS & 28.87 & 14.28 \\
\hline Boise City, ID & 24.50 & 34.09 \\
\hline Madison, WI & 52.22 & 7.23 \\
\hline Spokane, WA & 49.28 & 37.59 \\
\hline Pensacola, FL & 31.39 & 13.24 \\
\hline Canton, $\mathrm{OH}$ & NA & CBD \\
\hline
\end{tabular}

Regional Science and Urban Economics, Vol 42, No. 1-2 (January 2012): pg. 63-77. DOI. This article is (C) Elsevier and permission has been granted for this version to appear in e-Publications@Marquette. Elsevier does not grant permission for this article to be further copied/distributed or hosted elsewhere without the express permission from Elsevier. 
NOT THE PUBLISHED VERSION; this is the author's final, peer-reviewed manuscript. The published version may be accessed by following the link in the citation at the bottom of the page.

City

Saginaw, MI

\section{Quadratic estimate miles} from CBD
Non-parametric estimate miles from CBD

(1) Coefficients used come from Tables (4) and (8).

(2) Quadratic Estimates are calculated as the maximum between the Debt/Income Ratio and the Denial Rate Equation $=\beta_{1, D / I}$ (miles $)+\beta_{2}$, $\mathrm{D} / \mathrm{I}\left(\right.$ miles $\left.^{2}\right)-\beta_{1, \text { Denial }}($ miles $)-\beta_{2}$, Denial $\left(\right.$ miles $\left.^{2}\right)$, or miles $=\left(\beta_{1}\right.$, Denial $-\beta_{1}$,

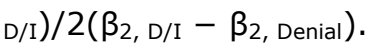

*Indicates statistically significant coefficients on both $\beta_{1}$ terms from tables (4) and (8).

\#Indicates regression estimated with poly-centric model.

\subsection{Credit sorting patterns across MSAs}

To sort out how MSA characteristics relate to observed mortgage debt-to-income ratio patterns, we examine the empirical relationship between credit sorting patterns and measures of local government sector structure, income, unemployment, geographic attributes, size, and demographic characteristics. The credit sorting patterns (the dependent variables) are based on the point estimates for the quadratic models reported in Table 5, as explained below. We do not conduct similar analysis for the locally weighted regression results as the locally weighted credit sorting patterns are complicated for some cities and difficult to summarize in the simple qualitative terms needed for the analysis. The specific factors used as independent variables are drawn from the 2000 Census and are defined as follows.

Several of the variables are included because they are factors thought to be associated with urban sprawl. These variables include the local government structure variables and income. Jurisdictions is defined as the number of cities, towns, and county governments in the MSA. Non-overlapping Jurisdictions is a dummy variable indicating that the MSA is in a New England state or Virginia, the only states that do not have functioning county jurisdictions that overlap with lower level municipal jurisdictions. The greater the number of competing jurisdictions, the stronger the potential Tiebout effect and the greater the spatial variation in tax and service bundles available to households, both of which affect spatial sorting by households across the MSA. The absence of overlapping county-municipal jurisdictions leads to greater Tiebout competition for a given number of local

Regional Science and Urban Economics, Vol 42, No. 1-2 (January 2012): pg. 63-77. DOI. This article is (C) Elsevier and permission has been granted for this version to appear in e-Publications@Marquette. Elsevier does not grant permission for this article to be further copied/distributed or hosted elsewhere without the express permission from Elsevier. 
jurisdictions ( Campbell, 2004, Turnbull and Djoundourian, 1993 and Turnbull and Tasto, 2008). The variable Central City Primacy is defined as the central city population divided by the total population of the MSA. Greater central city primacy means that a larger proportion of the MSA labor market lies within the central city jurisdiction. This may decrease urban sprawl by reducing the Tiebout effect of surrounding jurisdictions or increase flight-from-blight if central city performance declines with relative size ( Mills and Lubelle, 1997).

Median Income is included since household income has long been recognized as a primary factor driving urban sprawl ( Bruckner, 2000, Mills and Lubelle, 1997 and Nechyba and Walsh, 2004). Unemployment is the MSA unemployment rate in 2000 and is included as an indicator of the broad economic health of the MSA, a way to distinguish growing from declining urban areas. The variable Pct Long Commute measures the percent of households reporting work commutes of 45 min or longer. This variable picks up both the effects of the distribution of jobs across the urban area (since, for given MSA size, longer commutes likely indicate more concentrated job sites and shorter commutes more dispersed job sites) as well as overall traffic congestion.

The dummy variable Coastal indicates an MSA situated on one of the coasts. These MSAs not only have geographic limitations on the land area over which they can spread, being situated on a coast may also indicate a concentration of jobs associated with port activities that tend to remain centralized in the MSA. Size measures the size of the MSA in square miles and the variables Pct Nonwhite and Pct College measure the percent of population indicating their race is other than white and the percent of residents with at least a 4-year college degree.

We look first at the factors associated with whether the mortgage debt-to-income ratio is initially declining (Declining Debt/I=1) or rising (Declining Debt/I=0). With the dependent variable defined this way, we estimate both a linear probability model and probit model using the explanatory variables described above. The econometric specification for the linear probability model is ${ }^{10}$

Regional Science and Urban Economics, Vol 42, No. 1-2 (January 2012): pg. 63-77. DOI. This article is @ Elsevier and permission has been granted for this version to appear in e-Publications@Marquette. Elsevier does not grant permission for this article to be further copied/distributed or hosted elsewhere without the express permission from Elsevier. 
NOT THE PUBLISHED VERSION; this is the author's final, peer-reviewed manuscript. The published version may be accessed by following the link in the citation at the bottom of the page.

$$
\begin{aligned}
& \quad \text { Declining Debt } / I \\
& \left.=\alpha \beta_{1} \text { (Jurisdictions }\right) \\
& +\beta_{2}(\text { Non Overlapping Jurisdictions }) \\
& +\beta_{3}(\text { Central City Primacy })+\beta_{4}(\text { Median Income }) \\
& +\beta_{5}(\text { Unemployment })+\beta_{6}(\text { Pct Long Commute }) \\
& +\beta_{7}(\text { Coastal })++\beta_{8}(\text { Size })+\beta_{9}(\text { Pct Non White }) \\
& +\beta_{10}(\text { Pct College })+\varepsilon
\end{aligned}
$$

Table 10 reports the linear probability model results using White's robust standard error correction in column (1) and the probit model results in column (2). Looking at the linear probability model, the Jurisdictions coefficient is significantly positive, indicating that MSAs with greater local government fragmentation are more likely to exhibit the initially declining Debt/I associated with unconstrained households living closer to the CBD. Non-overlapping Jurisdictions has a significantly negative coefficient, which suggests that the government fragmentation effect on the credit sorting pattern is weaker for MSAs in states without overlapping county-city governments. Finally, Pct Nonwhite is significantly negative; MSAs with larger nonwhite populations are less likely to exhibit the pattern with unconstrained households living closer to the CBD.

Table 10. Meta regressions of factors explaining credit sorting patterns.

\begin{tabular}{lllll} 
& \multicolumn{1}{c}{$(\mathbf{1})$} & \multicolumn{1}{c}{$(\mathbf{2})$} & \multicolumn{1}{c}{$\mathbf{( 3 )}$} & \multicolumn{1}{c}{$\mathbf{( 4 )}$} \\
Jurisdictions & $0.00212^{* *}$ & 0.0133 & -0.0004 & -0.0425 \\
& $(0.0009)$ & $(0.0102)$ & $(0.0008)$ & $(0.126)$ \\
Central city primacy & 0.0879 & 0.272 & $-0.760^{*}$ & $-6.860^{* * *}$ \\
& $(0.302)$ & $(0.751)$ & $(0.444)$ & $(2.110)$ \\
Coastal & 0.232 & $0.644^{*}$ & 0.167 & 0.129 \\
& $(0.150)$ & $(0.389)$ & $(0.196)$ & $(0.731)$ \\
Non-overlapping jurisdictions & $-0.356^{* *}-1.415^{* *}$ & $0.530^{* *}$ & \\
Pct non-white & $(0.176)$ & $(0.647)$ & $(0.234)$ & \\
Pct college & $-1.293^{* *}$ & $-3.528^{* *}$ & -1.084 & -2.300 \\
& $(0.629)$ & $(1.768)$ & $(0.960)$ & $(4.215)$ \\
& 1.641 & 4.568 & $6.331^{* * *}$ & $32.77^{* * *}$ \\
& $(1.687)$ & $(4.347)$ & $(1.973)$ & $(8.143)$ \\
& -0.226 & -1.028 & $-3.716^{*}$ & $-22.95^{*}$
\end{tabular}

Regional Science and Urban Economics, Vol 42, No. 1-2 (January 2012): pg. 63-77. DOI. This article is (C) Elsevier and permission has been granted for this version to appear in e-Publications@Marquette. Elsevier does not grant permission for this article to be further copied/distributed or hosted elsewhere without the express permission from Elsevier. 
NOT THE PUBLISHED VERSION; this is the author's final, peer-reviewed manuscript. The published version may be accessed by following the link in the citation at the bottom of the page.

(1) (2) (3) (4)

Pct long commute median income $(\$ 10,000)$

$(1.811) \quad(5.207) \quad(1.958)$ $0.0000 \quad 0.0000-0.0001^{* *}-0.0002^{* * *}$ $\begin{array}{llll}(0.0001) & (0.0000) & (0.0000) & (0.0000)\end{array}$

Unemployment

Size

Constant

Observations

R-squared
$7.119 \quad 19.21 \quad 8.494^{* *}$

$(4.495) \quad(11.84) \quad(3.933)$ $0.0000 \quad 0.0000 \quad 0.0001^{* * *}$ $(0.0001)(0.0001)(0.0000)$ $0.104-1.0111 .510^{* *}$

(0.712)

99

0.118
$(1.825) \quad(0.690)$ 99

47

0.455
$(12.11)$

$57.69^{* * *}$

(21.51)

$0.0004^{* *}$

(0.0001)

2.742

(2.534)

45

Robust standard errors in parentheses.

Column (1) shows results of a linear probability model where the dependent variable equals one if the debt-to-income ratio is initially declining $\left(\beta_{1}<0\right)$, and 0 otherwise.

Column (2) shows the same regression using probit estimation.

Column (3) shows results of a linear probability model where the dependent variable equals one if the debt-to-income ratio is initially declining and reaches a minimum inside the MSA ( $\beta_{1}<0$ and $\beta_{2}>0$, with trough estimated within 70 miles of $\mathrm{CBD}$ ).

Column (4) shows the same regression using probit estimation.

$* * \mathrm{p}<0.05$.

$* \mathrm{p}<0.1$.

$* * * \mathrm{p}<0.01$.

The probit estimates reported in the second column differ somewhat from the linear probability estimates. In the probit model, Jurisdictions is no longer significant (although the point estimate remains positive) and Coastal is now significant. The variables Nonoverlapping Jurisdictions and Pct Nonwhite remain significant, as in the linear probability model.

Almost all of the MSAs exhibiting initially rising Debt/I with distance do not exhibit declining ratios at any point inside the MSA. The MSAs exhibiting initially falling Debt/I, however, are mixed in terms of whether the ratio reaches a minimum and then rises inside the MSA or declines monotonically throughout. To further examine the MSAs with initially declining Debt/I, we define Convex Debt/I as a dummy variable indicating that the mortgage debt-income ratio reaches a minimum and rises inside the MSA. MSAs with Convex Debt $/ I=1$ are MSAs with credit sorting consistent with unconstrained

Regional Science and Urban Economics, Vol 42, No. 1-2 (January 2012): pg. 63-77. DOI. This article is (C) Elsevier and permission has been granted for this version to appear in e-Publications@Marquette. Elsevier does not grant permission for this article to be further copied/distributed or hosted elsewhere without the express permission from Elsevier. 
households inside the urban area and credit constrained households exhibiting DTQ behavior in the suburbs. MSAs with Convex Debt $/ I=0$ exhibit no DTQ behavior throughout.

The third and fourth columns in Table 10 report the linear probability and probit estimates for this model, respectively. The two estimation methods yield qualitatively identical results for this subsample of MSAs. Once again, the structure of the local public sector matters. The significant negative coefficient on Central City Primacy implies that urban areas with relatively large central city jurisdictions are less likely to exhibit drive-'til-you-qualify behavior by creditconstrained households in the suburbs. The significant positive Nonoverlapping Jurisdictions coefficient indicates that these MSAs are more likely to exhibit credit-constrained households sorting into the suburbs.

MSAs with higher median income, by itself a factor driving sprawl, are less likely to exhibit credit-constrained DTQ behavior in the suburbs. Both a greater percent of college educated residents and higher unemployment rates increase the probability of the convex debt-to-income associated with DTQ behavior nearer the periphery. To the extent that older declining rust belt MSAs have higher unemployment than other cities, this last result suggests that older rust belt urban areas are more likely to exhibit the DTQ location behavior, confirming the pattern casually observed in Table 1 , Table 2 and Table 3.

\section{Conclusion}

This paper introduces credit quality considerations into the Alonso-Muth urban consumer model to derive credit quality spatial sorting patterns implied by household location equilibrium. The specific pattern of rising or declining credit quality with distance from the CBD depends upon the mix of credit-constrained and unconstrained households in the urban area. Our examination of the 100 largest MSAs in 2004 shows several basic patterns consistent with that predicted by the model. Urban areas exhibiting the drive-'til-youqualify behavior of credit-constrained households in their interiors tend to exhibit the pattern of rising credit quality with distance throughout. Urban areas exhibiting unconstrained household behavior in their

Regional Science and Urban Economics, Vol 42, No. 1-2 (January 2012): pg. 63-77. DOI. This article is (C) Elsevier and permission has been granted for this version to appear in e-Publications@Marquette. Elsevier does not grant permission for this article to be further copied/distributed or hosted elsewhere without the express permission from Elsevier. 
interiors, on the other hand, either exhibit that pattern throughout or credit-constrained household behavior in their suburbs. Further analysis shows that, for this group, weaker central city primacy and greater unemployment increase the probability of observing creditconstrained behavior in the suburbs.

The long run goal of housing policy in the U.S. has been to make homeownership more accessible to a wider range of households. The credit-sorting behavior of households emphasized here, however, suggests that one unanticipated side-effect of such policies and financing innovations may be to introduce spatial patterns of credit quality capable of reinforcing the type of default contagion effects recently observed in local housing markets.

\section{References}

Alonso, 1964 W. Alonso Location and Land Use Harvard University Press, Cambridge, MA (1964)

Bruckner, 2000 J.K. Bruckner Urban sprawl: diagnosis and remedies International Regional Science Review, 23 (2000), pp. 160-171

Campbell, 2004 R.J. Campbell Leviathan and fiscal illusion in local government overlapping jurisdictions Public Choice, 120 (2004), pp. 301-329

Cleveland, 1979 W. Cleveland Robust locally weighted regression and smoothing scatterplots Journal of the American Statistical Association, 74 (1979), pp. 829-836

deleeuw, $1971 \mathrm{~F}$. deleeuw The demand for housing-a review of the crosssection evidence The Review of Economics and Statistics, 53 (1971), pp. $1-10$

Goodman and Kawaii, 1986 A.C. Goodman, M. Kawaii Functional form, sample selection, and housing demand Journal of Urban Economics, 20 (1986), pp. 155-167|

Hanushek and Quigley, 1980 E. Hanushek, J. Quigley What is the price elasticity of housing demand? The Review of Economics and Statistics, 62 (1980), pp. 449-454

Harding et al., 2009 J.P. Harding, E. Rosenblatt, V.W. Yao The contagion effect of foreclosed properties Journal of Urban Economics, 66 (2009), pp. $164-178$

Immergluck and Smith, 2006 D. Immergluck, G. Smith The external costs of foreclosure: the impact of single-family mortgage foreclosures on property values Housing Policy Debate, 17 (2006), pp. 57-79

Regional Science and Urban Economics, Vol 42, No. 1-2 (January 2012): pg. 63-77. DOI. This article is (C) Elsevier and permission has been granted for this version to appear in e-Publications@Marquette. Elsevier does not grant permission for this article to be further copied/distributed or hosted elsewhere without the express permission from Elsevier. 
NOT THE PUBLISHED VERSION; this is the author's final, peer-reviewed manuscript. The published version may be

accessed by following the link in the citation at the bottom of the page.

Leventis, 2009 A. Leventis The impact of distressed sales on repeattransaction house price indexes Research Paper, Federal Housing Finance Agency (2009)

Lin et al., 2009 Z. Lin, E. Rosenblatt, V.W. Yao Spillover effects of foreclosure on neighborhood property values Journal of Real Estate Finance and Economics, 38 (2009), pp. 387-407

Mayo, 1981 S. Mayo Theory and estimation in the economics of housing demand Journal of Urban Economics, 10 (1981), pp. 95-116

McMillen, 2001 D. McMillen Nonparametric employment subcenter identification Journal of Urban Economics, 50 (2001), pp. 448-473

McMillen, 2004 D. McMillen Employment densities, spatial autocorrelation, and subcenters in large metropolitan areas Journal of Regional Science, 44 (2004), pp. 225-243

Mian and Sufi, 2009 A. Mian, A. Sufi The consequences of mortgage credit expansion: evidence from the U.S. mortgage default crisis Quarterly Journal of Economics, 124 (2009), pp. 1449-1496

Mills and Lubelle, $1997 \mathrm{E}$. Mills, S. Lubelle Inner cities Journal of Economic Literature, 35 (1997), pp. 727-756

Muth, 1969 R.F. Muth Cities and Housing University of Chicago Press, Chicago, IL (1969)

Meyer and Pence, 2009 C. Meyer, K. Pence Subprime mortgages: what, where, and to whom? E. Glaeser, J. Quigley (Eds.), Housing Markets and the Economy: Risk, Regulation, and Policy, Lincoln Institute of Land Policy, Cambridge (2009), pp. 149-196

Nechyba and Walsh, 2004 T.J. Nechyba, R.P. Walsh Urban sprawl Journal of Economic Perspectives, 18 (2004), pp. 177-200

Pavlov, 2000 A. Pavlov Space-varying regression coefficients: a semiparametric approach applied to real estate markets Real Estate Economics, 28 (2000), pp. 249-283

Turnbull, 1992 G.K. Turnbull Location, housing, and leisure demand under local employment Land Economics, 68 (1992), pp. 62-71

Turnbull, 1995 G.K. Turnbull Urban Consumer Theory. AREUEA Monograph Series, No. 2, Urban Institute Press, Washington, DC (1995)

Turnbull and Djoundourian, 1993 G.K. Turnbull, S.S. Djoundourian Overlapping jurisdictions: substitutes or complements? Public Choice, 75 (1993), pp. 213-245

Turnbull and Tasto, 2008 G.K. Turnbull, M.T. Tasto Independent cities and counties in Virginia: substitute jurisdictions? Urban Studies, 45 (2008), pp. 53-66

is The authors wish to thank, without implicating, Dan McMillen and an anonymous reviewer for helpful suggestions.

Regional Science and Urban Economics, Vol 42, No. 1-2 (January 2012): pg. 63-77. DOI. This article is (C) Elsevier and permission has been granted for this version to appear in e-Publications@Marquette. Elsevier does not grant permission for this article to be further copied/distributed or hosted elsewhere without the express permission from Elsevier. 
NOT THE PUBLISHED VERSION; this is the author's final, peer-reviewed manuscript. The published version may be accessed by following the link in the citation at the bottom of the page.

\section{Corresponding author.}

${ }^{1}$ See Turnbull (1995) for a survey of the early literature establishing these relationships.

2 Alonso, 1964 and Muth, 1969 provide the seminal treatments of urban consumer location theory. See Turnbull (1995) for a review of subsequent extensions and applications of the canonical framework.

${ }^{3}$ Household utility is also a function of commuting distance in Alonso's version of the model. Alonso's model, however, can be shown to be a special case of the Muth formulation extended to allow for labor-leisure choice (Turnbull, 1992 and Turnbull, 1995).

${ }^{4}$ All results exclude the Southwest direction. The estimates of our coefficients of interest, $\beta_{1}$ and $\beta_{2}$, are not sensitive to direction excluded.

5 The lone exception to using the Emporis data is for Washington D.C, where the tallest building is the Washington monument. Because the Washington monument is a landmark and not used for commerce or government activity, we designate the U.S. Capitol building as the CBD.

${ }^{6}$ HMDA requires banks, savings associations, credit unions, and other mortgage lending institutions to report select loan and loan application data. The HMDA data, however, does not cover mortgages made by non-depository lenders, a significant source of subprime loans, so our credit quality measures are not comprehensive.

7 The coefficient on $\beta_{2}$ was set equal to zero for New York because the second order effect for Miles $i$ is not statistically significant from zero.

${ }^{8}$ For brevity, we do not report the coefficients of the control variables for all cities; they are available from the authors upon request. All regressions include a constant term, median income, percentage of vacant units, median home value, employment rate, percentage of college educated adults, percentage of non-white residents, percentage of new residents, average commute time, and a set of dummy variables for the direction from the CBD (SW direction omitted).

${ }^{9}$ In the interest of brevity we do not report the coefficients from the control variables for all cities; they are available from the authors upon request. All regressions are estimated with a constant term and control for median income, percentage of vacant units, median home value, employment rate, percentage of college educated adults, percentage of non-white residents, percentage of new residents, average commute time, and a set of dummy variables for direction from the CBD (SW direction omitted).

${ }^{10}$ The probit specification uses the same variables as the linear probability model except for results reported in column (4) of Table 10 where

Regional Science and Urban Economics, Vol 42, No. 1-2 (January 2012): pg. 63-77. DOI. This article is @ Elsevier and permission has been granted for this version to appear in e-Publications@ Marquette. Elsevier does not grant permission for this article to be further copied/distributed or hosted elsewhere without the express permission from Elsevier. 
NOT THE PUBLISHED VERSION; this is the author's final, peer-reviewed manuscript. The published version may be accessed by following the link in the citation at the bottom of the page.

Non-overlapping Jurisdictions is excluded because it perfectly predicts the dependent variable.

Regional Science and Urban Economics, Vol 42, No. 1-2 (January 2012): pg. 63-77. DOI. This article is (C Elsevier and permission has been granted for this version to appear in e-Publications@Marquette. Elsevier does not grant permission for this article to be further copied/distributed or hosted elsewhere without the express permission from Elsevier. 